\title{
ROLE OF MULTIVARIATE APPROACHES IN FLORISTIC DIVERSITY OF MANOOR VALLEY (HIMALAYAN REGION), PAKISTAN
}

\author{
RAHMAN, I. U. ${ }^{1,2}-$ AfZAL, A. ${ }^{1 *}-$ IQBAL, Z. ${ }^{1}-$ ABD_ALlAH, E. F. ${ }^{3 \dagger}-$ ALQARAWI, A. A. ${ }^{3}-$ \\ CALIXTO, E. S. ${ }^{4 *}-$ Ali, N. ${ }^{1}-$ IJAZ, F. ${ }^{1}-$ KAUSAR, R. ${ }^{5}-$ ALSUBEIE, M. S. ${ }^{6}-$ IQBAL, M. $^{1}{ }^{1}$ SHAH, M. ${ }^{7}$ \\ ${ }^{I}$ Department of Botany, Hazara University, Mansehra-21300, KP, Pakistan \\ ${ }^{2}$ William L. Brown Center, Missouri Botanical Garden, P.O. Box 299, St. Louis, MO 63166- \\ 0299, USA \\ ${ }^{3}$ Department of Plant Production, College of Food \& Agricultural Sciences, King Saud \\ University, P.O. Box 2460, Riyadh 11451, Saudi Arabia \\ ${ }^{4}$ Department of Biology, University of Sao Paolo, SP, Brazil \\ ${ }^{5}$ Department of Environmental Sciences, International Islamic University, Islamabad, Pakistan \\ ${ }^{6}$ Biology Department, College of Sciences, Al Imam Mohammad Ibn Saud Islamic University, \\ Riyadh 11451, Saudi Arabia \\ ${ }^{7}$ Department of Biological Sciences, Faculty of Science, King Abdulaziz University, Jeddah \\ 21589, Saudi Arabia \\ *Corresponding author \\ e-mail: aftabafzalkiani@yahoo.com, calixtos.edu@usp.br \\ ORCID ID: ${ }^{8} 0000-0003-3312-7975 ;{ }^{* 0000-0002-8509-8953 ~}$
}

(Received $9^{\text {th }}$ Oct 2018; accepted $5^{\text {th }}$ Dec 2018)

\begin{abstract}
The main source of botanical information of a particular area is its floristic checklists. Floristic study of any given area helps to evaluate the plant wealth and its potential values. To assess floristic diversity of an unexplored remote valley (Manoor Valley), frequent field visits were arranged in different growing seasons during 2015 to 2018. The life form classes and leaf spectra of all plant species were determined and further classified according to the Raunkiaer classification. Plant species were identified and deposited to the Herbarium at Hazara University, Mansehra. The floristic diversity consisted of 354 plant species belonging to 93 families. Herbaceous was the most representative growth form, with 259 species, followed by shrubs with 52 species, trees with 42 species and parasitic plant with one species. Asteraceae was the leading family with 36 species, followed by Lamiaceae species. Furthermore, results indicated the dominancy of Therophytic plants and Nanophyllous and Microphyllous leaves. July marked the peak of flowering period and September the peak of fruiting period. This study provided the first insight of the floristic inventory in relation to multivariate approaches in this unexplored area. This regional novel launched list may serve as a vital resource for all future endeavors in the field of phytosociological, pharmacological and conservational studies of natural resources.
\end{abstract}

Keywords: floristic checklist, Asteraceae, principal components analysis, species response curve

\section{Introduction}

Vegetation is an umbrella term that indicates plant life of a region (Rahman et al., 2018a) or, in other words, a group of plants growing together in a particular area and may be characterized by its component species (Malik, 1990). Flora is a priceless donation of nature upon which the mankind always relies (Khan et al., 2013). Flora 
comprises the total plant species of any specific geographic region, which are characteristic of a geological period or in habit a particular ecosystem (Durrani et al., 2005). According to the report of Walter and Hamiston (1993), approximately 422,000 flowering plants have been reported globally (Rahman et al., 2016a). Pakistan is blessed with diverse flora due to variability in climate (Rahman et al., 2018b) and presents about 6000 flowering plant species (Rahman et al., 2016a).

The main source of botanical information of a particular area is its floristic checklists (Safidkon et al., 2003). Floristic study of any given area helps to evaluate the plant wealth and its potential values (Shaheen et al., 2016). Local plant species documentation is very necessary to introduce specific floral species of the local area, their occurrence and finding new species (Ali, 2008). Many workers have contributed comprehensive floristic checklists of local flora in different regions (Qureshi, and Bhatti, 2008; Jabeen et al., 2009; Shaheen et al., 2011).

In these studies of floristic checklist, besides evaluating the species richness, it is also necessary to observe the plant life form, leaf size and phenology over the year (Rahman et al., 2018a). Life form is the indicator of micro and macroclimate and it is characterized by plant adaptation to certain ecological conditions (Shimwell, 1971). As the plants arranged by the Raunkiaer (1934) in order to form classes on the basis of their life form, five major classes were formed (Hussain and Perveen, 2009) which includes: Phanerophytes, Hemicryptophytes, Cryptophytes, Chamaephytes, and Therophytes. Plants are also classified on the basis of leaf sizes and this has been exceptionally helpful for association mapping of vegetation. The leaf size knowledge helps in understanding physiological processes of plants (Oosting, 1956). For instance, biotic agencies are the chief causes for changing the biological spectrum in a given floristic zone (Amjad, 2012).

Phenology demonstrates the relationship of plant development to seasonal variations as well as photoperiod to program their developmental stages and natural exercises appropriated with the normal seasonal conditions (Manske, 2006). Essentially, timings and interim of the intermittent natural occasions (biological events) among stages of plant species give a foundation of gathering and synthesizing quantitative data of plant communities, which are directly linked with phenology (Singh and Singh, 1992). There is a synchronization of phenological behavior of the plant species and the various elements of the environmental conditions that plants are discussed, the organic tickers (biological clocks). These are habitually controlled by external environmental stimuli (Zhang et al., 2006, Vilela et al., 2017). Leaf growth, leaf fall, flowering and fruiting of species occur in specific seasons of the year and the phenology of life forms varies and is associated with day length/ temperature (Rahman et al., 2018a). As reported by Ahmed (2017), the blossoming and fruiting could be connected with the climatic conditions for posterity survival. Cornejo-Tenoria and Ibarra-Manriquez (2007) recorded blossoming and fruiting behavior on month-to-month premise. Bhat and Muralli (2001) depicted the climatic factors, for example, precipitation, water accessibility, change in day length and temperature additionally triggers the phonological occasions and because of temperature contrast, there is huge variety among species in various climatic zones.

In this way, the unexplored remote valley Manoor Valley, Pakistan, has great potential for flourishing a rich plant biodiversity due to the presence of diverse microhabitats and topographic features. Since biodiversity is greatly affected by different environmental factors (Khan, 2012) and is facing serious challenges due to 
anthropogenic activities like deforestation and over grazing (Ijaz, 2014), it is fundamental to develop floristic checklist studies. Hence, the current study was designed to explore the biodiversity and document the floristic checklist of Manoor Valley. This study provides the updated insights into the floristic diversity of the area and it might also be very helpful for the future plant ecological, conservational and ecophysiological studies.

\section{Materials and methods}

\section{Study area (Manoor Valley)}

There are two sub-valleys in Kaghan Valley, i.e. Naran Valley and Manoor Valley. Naran Valley is located in upper Kaghan Valley, while Manoor Valley is reached from the main Kaghan Valley road at the junction 'Mahandri' (Fig. 1) and is about $50 \mathrm{Km}$ north of Balakot (Rahman et al., 2016a, b). Floristically, the valley is very rich, diverse and unexplored. To date, very few references are available on floral studies of the area including few reports of medicinal studies (Rahman et al., 2016a, b, c; 2018c) and preliminary checklist (Rahman et al., 2018a).

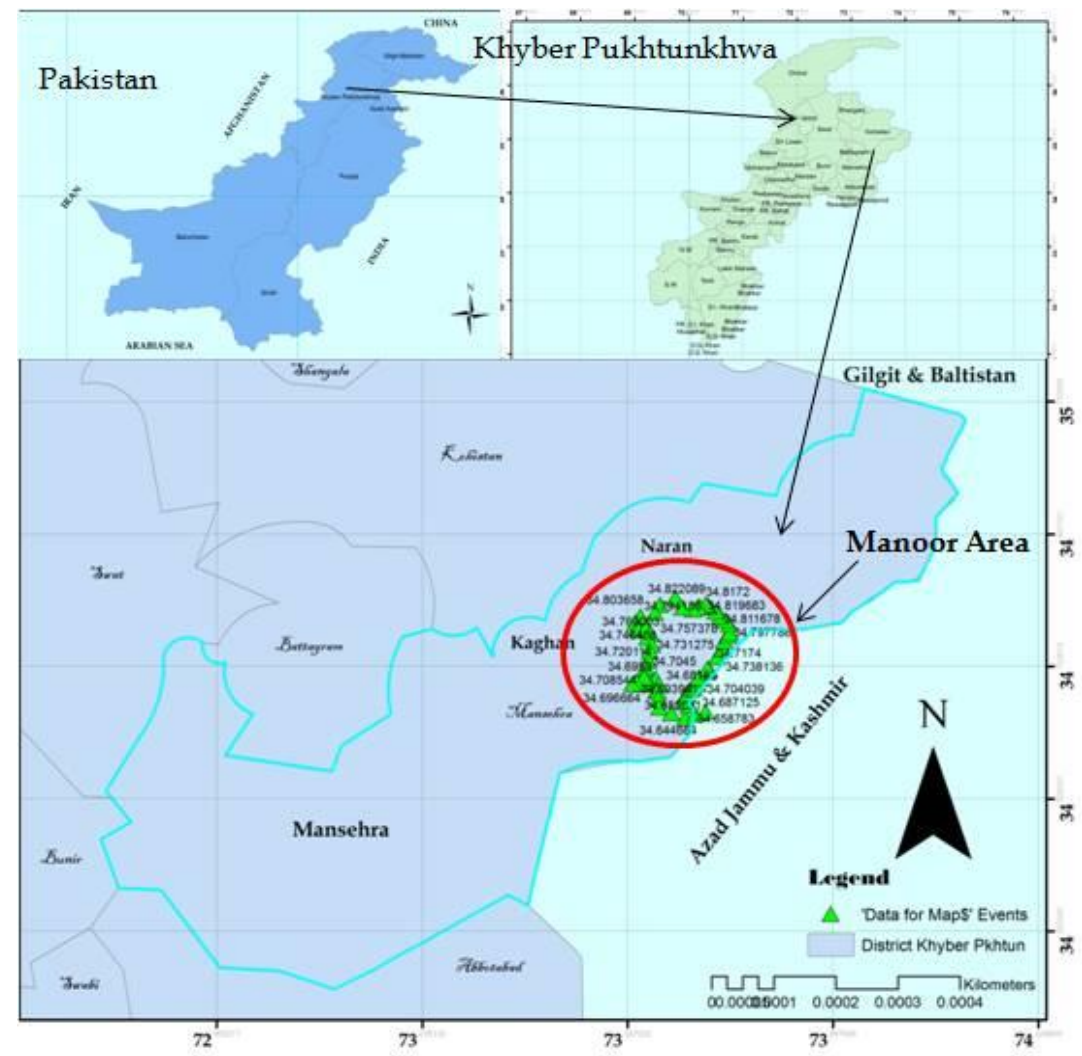

Figure 1. Map of Mansehra area showing the Manoor Valley, Pakistan

\section{Field work, equipments, identification and preservation}

From 2015 to 2018, field surveys were conducted to cover the understory area for collection of data regarding plant species. For this purpose, the study area was divided into 133 sampling sites or stations, where they were classified into life form and leaf 
sizes classes following Raunkiær (1934); Oosting (1956); Hussain (1989). Field notebook, pen, pencil, polythene bags, tags, trowel, scissors, camera, newspaper, plants presser and twig cutter were used during survey (Ijaz, 2014). The collected plants were properly dried and pressed by using newspaper for about 2-4 weeks at normal temperature. Then plants were treated or poisoned with chemical solution for preservation and mounted on standard herbarium sheets. Then data were shifted from field notebook on herbarium label of standard herbarium sheets. This herbarium label was pasted on right side of herbarium sheets (Ijaz, 2014; Ahmed, 2017). The size of herbarium sheet was standardized (11.5 x 16.5) (Ijaz, 2014). The specimens were identified by using the Flora of Pakistan (Nasir and Ali, 1971-1989; Ali and Nasir, 1989-1991; Ali and Qaiser, 1995-2017) and the identified specimens were deposited in the Herbarium of Hazara University, Mansehra, Pakistan (HUP).

\section{Multivariate approaches}

Recorded plant species data was analyzed through various multivariate approaches by using different statistical packages. CANOCO 5 version was used (Rokaya et al., 2012) for multivariate ordination analyses like 'dominance curve' (DC), 'principal components analysis' (PCA) (Rokaya et al., 2012, 1992) and species response curve (SRC). PCA was determined to examine the correlation between 354 plant species and 4 growth form categories. PC-ORD 5 was used for correlation and regression coefficient (Rahman et al., 2018c). The correlation and regression coefficient evaluates the variables behavior on different axes. Chord Diagram was made through $\mathrm{R}$ software using package 'circlize' (Gu et al., 2014).

\section{Results}

\section{Floristic diversity}

Flora of the study area consisted of 354 plant species belonging to 93 families. In this total, the leading plant habit was herbaceous having 259 spp., followed by shrubs with 52 spp., trees with 42 spp., and parasitic plant with one species, respectively (Fig. 2). Asteraceae was the leading families with 36 species, followed by Lamiaceae with 24 species, Rosaceae with 22 species. For a complete inventory see Appendix.

Based on biological spectrum, the flora was dominated by Therophytes (116 spp.) followed by Hemicryptophytes (90 spp.), Nanophanerophytes (48 spp.) and Chamaephytes (29 spp.) (Fig. 3). On the basis of leaf spectra, the study area was dominated by Nanophyll and Microphyll with 105 spp. and 100 spp., respectively, followed by Mesophyll (64 spp.), Leptophyll (58 spp.), and Megaphyll (23 spp.) (Fig. 4). Further, four species (Cuscuta reflexa, Ephedra girardiana, Equisetum arvense and Periploca aphylla) were found as Aphyllous. For a complete inventory of biological spectrum and leaf size see Appendix.

The flowering data showed that July marked the peak of flowering season where 90 plant species had flowers, followed by June with 80 species. In May, flowering was observed in 68 species, followed by April with 42 species. The fruiting data showed that September was the peak fruiting season for 82 plant species, followed by August for 79 species. 


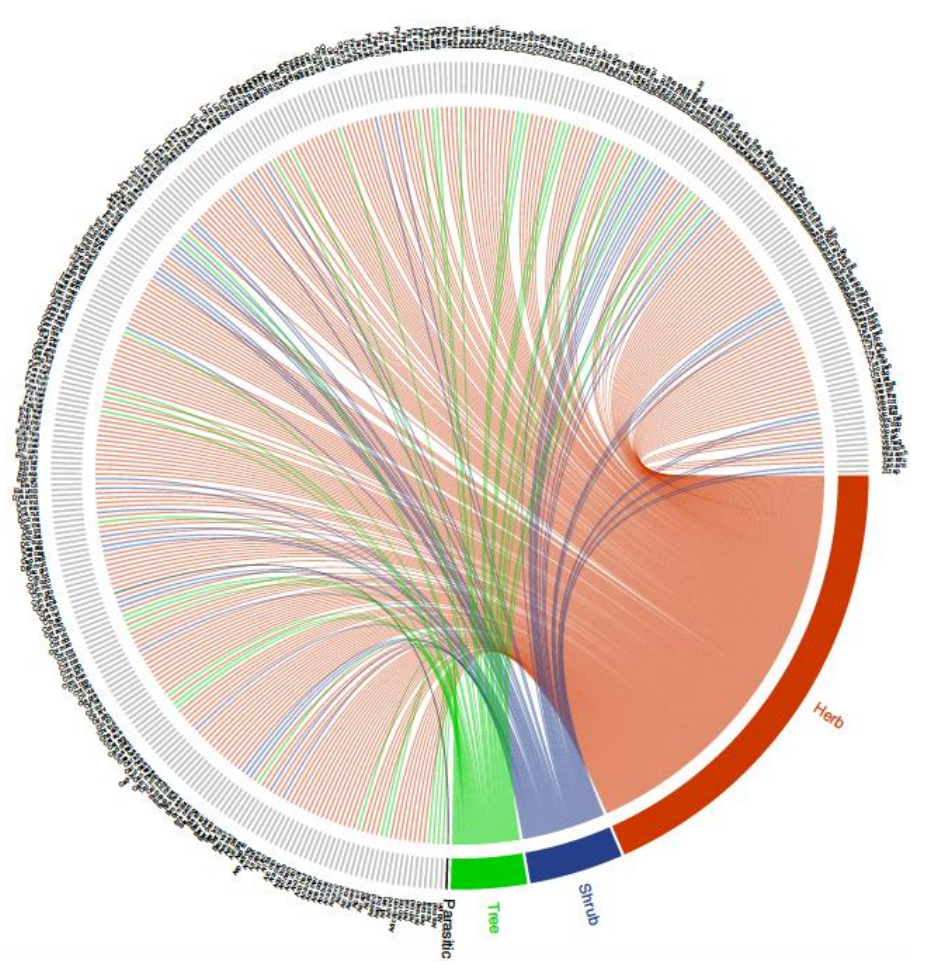

Figure 2. Distribution of the 354 species found in Manoor Valley, Pakistan, among the growth plant habit: herb (red), shrub (blue), tree (green) and parasitic plant (black). Herbs are represented by 259 species, shrubs by 52 species, trees by 42 species and parasitic plants by 1 species. The full name of species is in Appendix

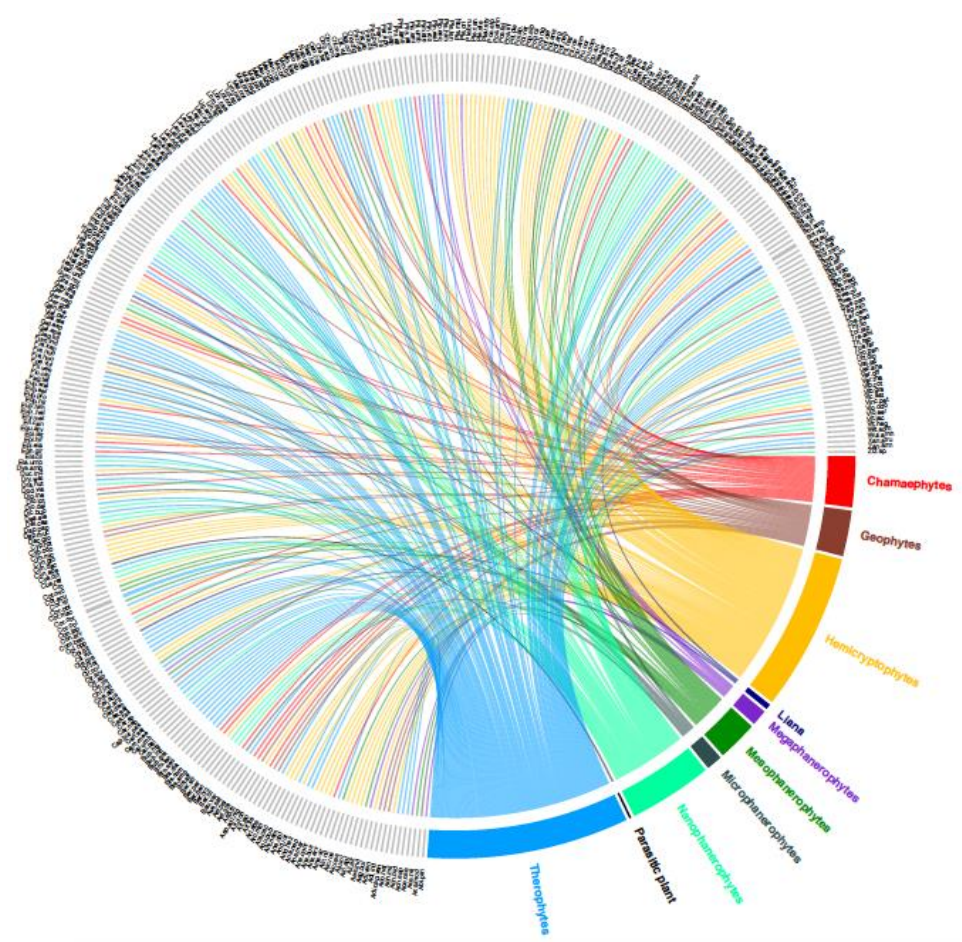

Figure 3. Distribution of the 354 species found in Manoor Valley, Pakistan, among the life form classes. The full name of species is in Appendix 


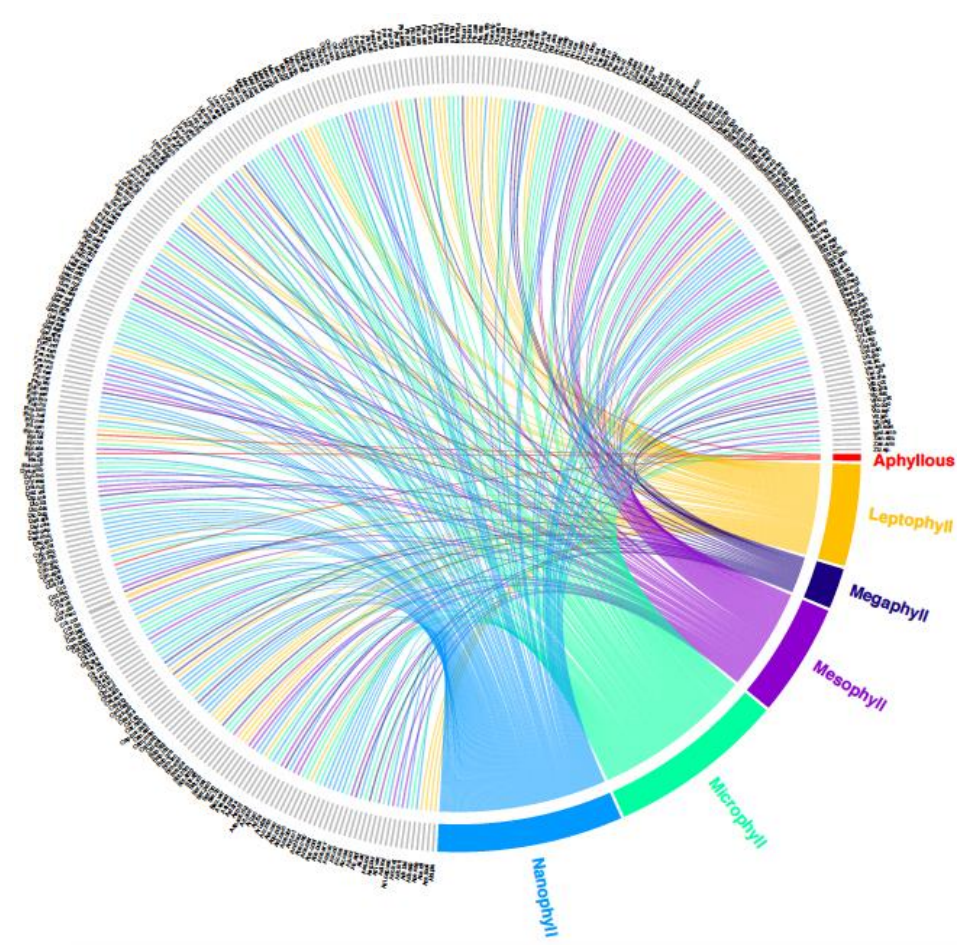

Figure 4. Distribution of the 354 species found in Manoor Valley, Pakistan, among the leaf size classes. The full name of species is in Appendix

\section{Correlation and regression coefficient}

The correlation and regression coefficient variables behaved differently on different axes. On axis 1, highly positive correlation (1.000) and highest positive tau value (0.957) was recorded for herbaceous plant habit, while on axis 2, positive correlation value was recorded $(0.24)$ but negative tau value $(-0.095)$ was logged for herbaceous growth form in comparison with all other growth forms (Fig. 5A). Moreover, on axis 1, highly negative correlation (-0.705) and highly negative tau value $(-0.766)$ was recorded for shrubby plant habit, while on axis 2 , highly positive correlation value (0.706) and highest positive tau value (0.766) was logged (Fig. 5B).

The correlation and regression results of tree growth form showed negative correlation (-0.586) and positive tau value (-0.464) on axis 1 and highly negative correlation value $(-0.807)$ and highest negative tau value $(-0.696)$ was logged on axis 2 (Fig. 5C). Further, the parasitic growth form on axis 1 showed minimum negative correlation (-0.74) and minimum negative tau value (-0.055) and similarly, minimum negative correlation value (-0.014) and minimum positive tau value (-0.089) was logged on axis 2 in comparison with all other growth forms (Fig. 5D). Axis 1 was dominated by herbaceous growth form, while axis 2 by shrubby plant habit (Fig. 5A-D).

\section{Principle components analysis (PCA)}

The PCA results revealed that 259 plant species were most frequently cited positively and significantly correlated with herbaceous growth form (Fig. 6). Fifty-two plant species indicates positive influence towards the direction of shrubby growth form. Tree growth habit was most frequently cited and positively correlated with 40 plant 
species. Cuscuta reflexa was the only species assigned to parasitic growth form category (Fig. 6).

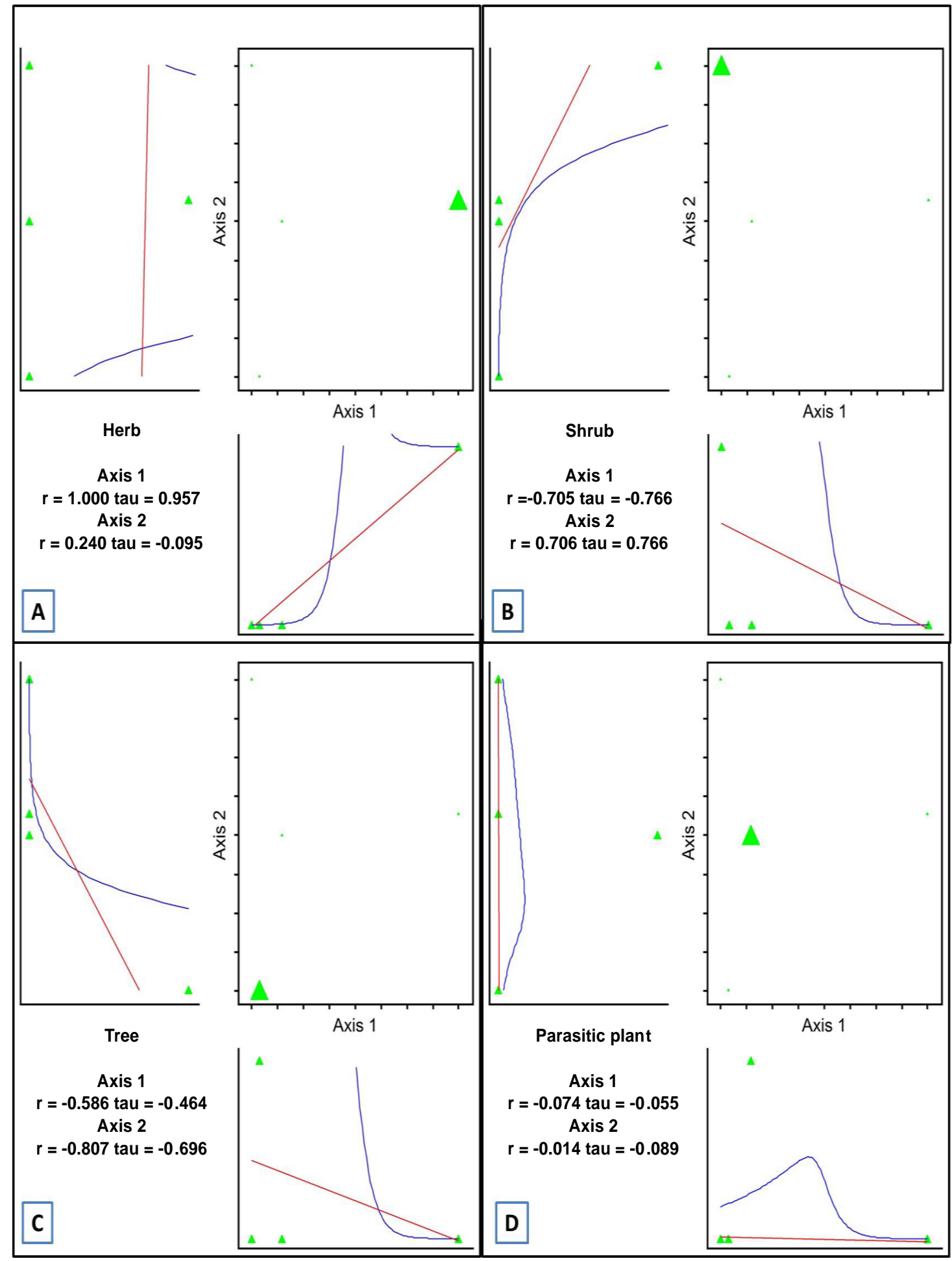

Figure 5. Correlation and regression coefficient of growth form on different axis: A) Herb, B) Shrub, C) Tree and D) Parasitic plant 


\section{Species response curve (SRC)}

The analysis clearly indicates highly significant differences $(F=451, p<0.00001$; Fig. 7) for herb category in comparison with all other growth form categories due to maximum number of species (Fig. 7A). This growth form category also revealed highest response $(99.3 \%)$. Nonetheless, shrub growth form also showed highly significance $(\mathrm{F}=415, \mathrm{p}<0.00001)$ due to its number of species in comparison with tree and parasitic plant habit and presented a response percentage of $55.1 \%$. Also tree growth form presented significant differences $(\mathrm{F}=142, \mathrm{p}<0.00001)$ and response percentage (29.6\%) in comparison with parasitic plant habit category. Parasitic plant showed nonsignificant differences $(\mathrm{F}=0.81, \mathrm{p}=0.63206)$ and response percentage $(0.2 \%)$ as given in the Table 1. Additionally, Figure $7 B$ illustrates the flow of species cited within each growth form category from top to bottom as enlisted in Table 1.

Table 1. Summary of fitted generalized linear models four response variables

\begin{tabular}{c|c|c|c|c}
\hline Response & Type & $\mathbf{R}^{\mathbf{2}}[\%]$ & $\mathbf{F}$ & $\mathbf{p}$ \\
\hline Herb & linear & 99.3 & 451 & $<0.00001$ \\
Shrub & linear & 55.1 & 415 & $<0.00001$ \\
Tree & linear & 29.6 & 142 & $<0.00001$ \\
Parasitic plant & linear & 0.2 & 0.81 & 0.63347 \\
\hline
\end{tabular}

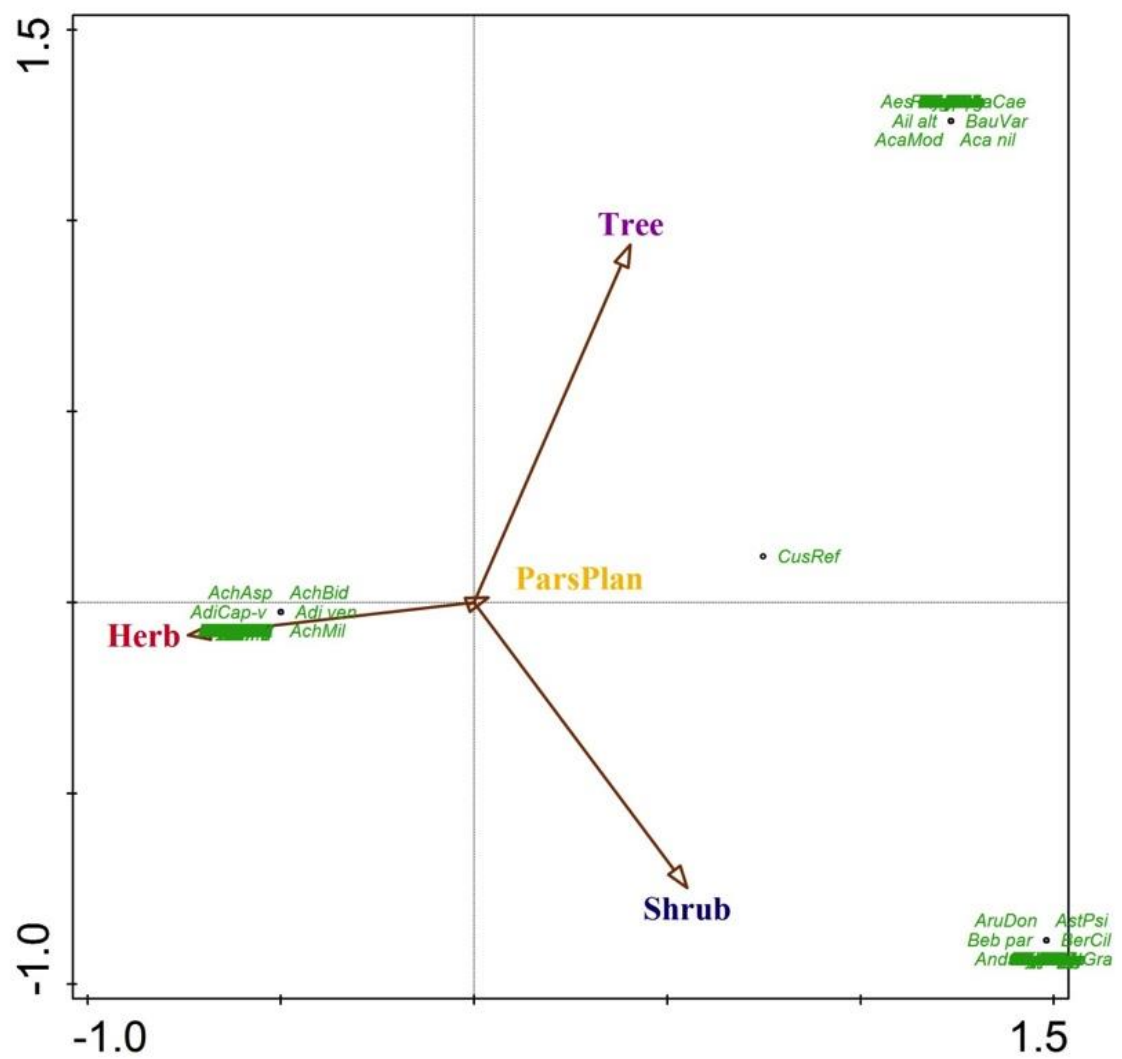

Figure 6. Principle component analysis indicating the association of plant species with their growth forms 

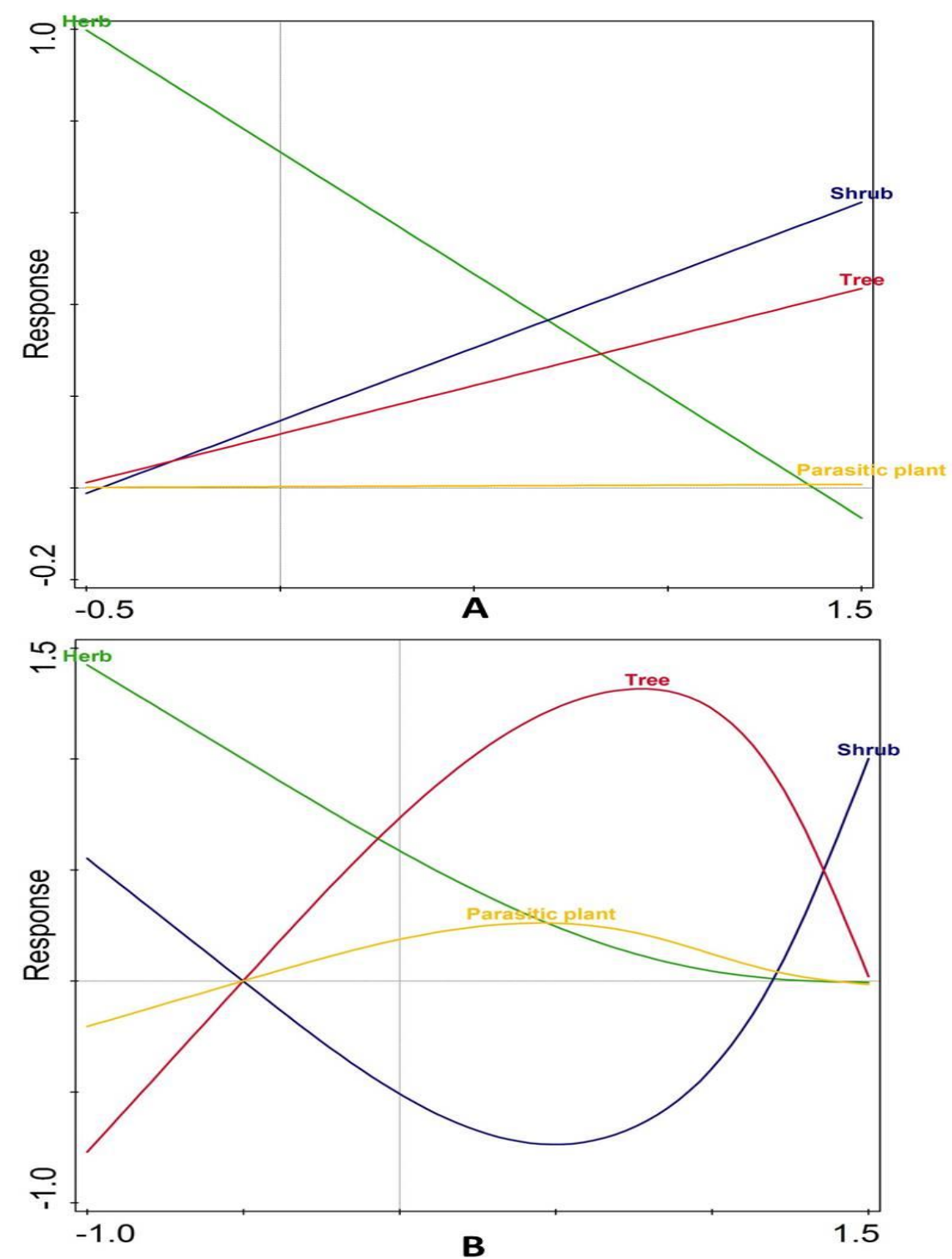

Figure 7. A) Growth form categories response curve illustrating the significance level and B) flow of species cited within each growth form category

\section{Discussion}

The results of this study showed that Manoor Valley, Pakistan, it is an area rich in plant species, presenting 354 species, being the herb habit most representative. Furthermore, it can be observed that the multivariate approaches showed significant differences, which supports the prediction and assertion that the herb habit is the principal plant habitat in this area.

Floristic structure is the main reflection of vegetation of any area (Rahman et al., 2018a). Plant species has its own ecological amplitude and interaction with its environment and also with other species (Giustiet al., 1995). The flora of Pakistan is diverse due to different ecological zones, diverse climatic and soil condition. In the present study, flora consisted of 354 species, where the dominating growth form was 
herbaceous with 259 species. In Pakistan, many researchers from different areas also mentioned herbaceous growth form as the leading one from their study areas (Ijaz et al., 2015; Khan et al., 2015a; Ijaz et al., 2016), which shows a predominance of herbaceous growth form in Pakistan.

Asteraceae was the leading familly with 36 species, followed by Lamiaceae with 24 species and Rosaceae with 22 species. Due to wide ecological amplitude, Asteraceae family are very diverse in habitat (Badshah et al., 2013). Khattak et al. (2015) found similar results in Karak, Pakistan and in addition Iqbal et al. (2015) also reported Asteraceae as the most predominant group in Malakand, Pakistan. On the other hand, Khan et al. (2015b) showed in a study made in Kabal (Swat), Pakistan, that Lamiaceae was the dominant family. Regardless of the family, Asteraceae and Lamiaceae appear to be the main plant families present in Pakistan's vegetation.

The flora of Manoor Valley was dominated by Therophytes, followed by Hemicryptophytes. Similarly, Badshah et al. (2013) observed Therophytes as the leading life form in Tank region, Pakistan. For various physiological processes of plants and plant communities leaf size plays a vital role (Oosting, 1956). On the basis of leaf spectra, Nanophyll and Microphyll were the most representatives. The species with Microphyllous leaves are rich due to ecological variation, which shows the percentage of different leaf form classes varied with rising altitudes and according to Cain and Castro (1959) Microphyllous species are the indication of steeps. Similar findings were observed by Saxina et al. (1987) who stated that the percentage of Microphyllous species was completely associated with the rising altitude.

Results showed that July had the flowering peak with 80 plant species, followed by June with 77 species (Fig. 8). These results are in agreement with those of Shrestha et al. (1998), where the authors noticed the blooming period from May to August in Kavrepalanchok, Nepal. As indicated by Marques et al. (2004), phenological period and atmosphere are associated with each other in terms of temperature, day length and precipitation or rainfall. Fruiting phase had peak in September and August (Fig. 9). Similar phenological scenario was reported by Morellato (1995) who reported that the blooming period begins toward the end of the dry season and at the starting of the wet season, thus fruiting takes place in dry season and that the next rainy period will offer appropriate conditions for seed germination (Morellato et al., 1989).

\section{Conclusion}

The present study indicated that the study area has rich plant biodiversity. Flora of Manoor Valley area consisted of 354 plant species, where the leading plant habit was herbaceous with 249 species and family was Asteraceae with 36 species. We can use these inventory lists as a vital resource for all future endeavors in the field of phytosociological, phytochemical, pharmacological and conservational studies of natural resources. Regarding the multivariate approaches, we can observe that these analyzes are extremely useful to show us significant differences in certain floristic survey studies, providing support and veracity in the discussions and conclusions found. Studies like this present are necessary to evaluate the plant richness and its potential value. 


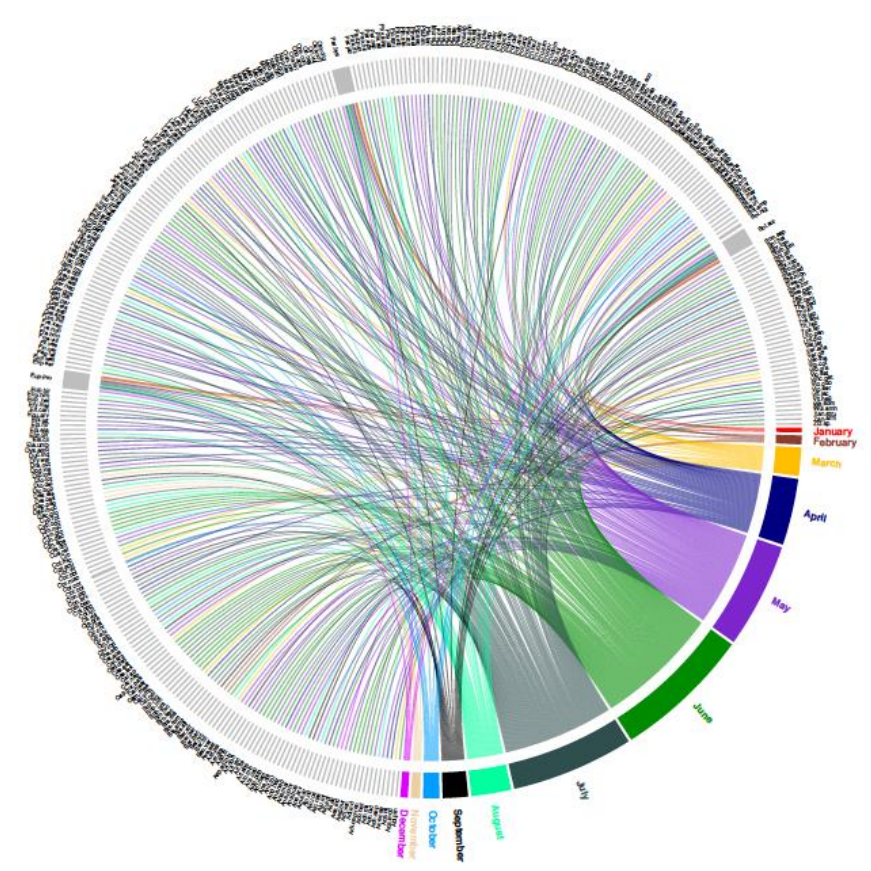

Figure 8. Distribution of the 354 species found in Manoor Valley, Pakistan, according to flowering period. The full name of species is in Appendix

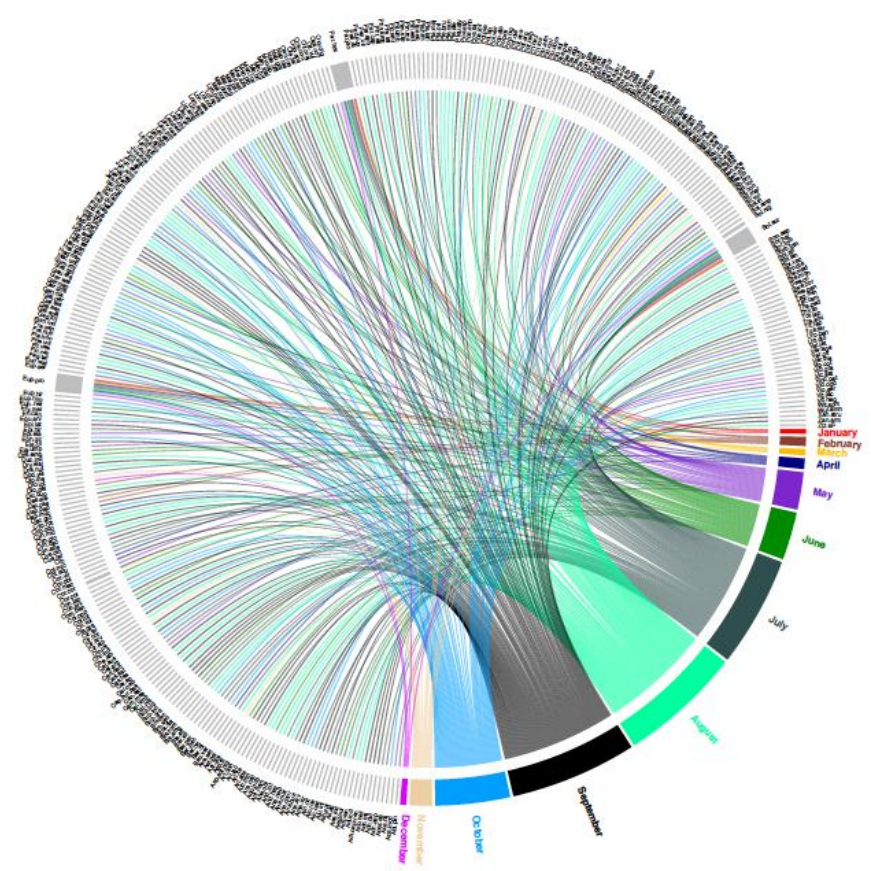

Figure 9. Distribution of the 354 species found in Manoor Valley, Pakistan, according to fruiting period. The full name of species is in Appendix

Author's Contributions. IUR conducted the fieldwork, collected data and plant species, and designed the map, FI helped in the herbarium work. IUR drafted the manuscript and ESC helped in analysis of the data, NA helped in organizing the data. AA and ZI supervised the work. EFA, AA and ZI critically reviewed the manuscript. IUR, ESC, EFA and NA revised the manuscript, AAA, MSA, RK, MS and MI helped in revision. All the authors have read and approved the final manuscript. 
Acknowledgements. First author would like to thank Higher Education Commission (HEC), Pakistan for granting scholarship under International Research Support Initiative Program (IRSIP) to conduct a research work at Missouri Botanical Garden, USA). The authors would like to extend their sincere appreciation to the Deanship of Scientific Research at King Saud University for its funding to the Research Group number (RG-1435-014).

\section{REFERENCES}

[1] Ahmed, J. (2017): Floristic diversity and ethnobotanical appraisal of Tehsil Oghi, District Mansehra, Pakistan. - M.Sc. Thesis (Botany), Govt. Post Graduate College, Mansehra, Pakistan.

[2] Ali, S. I. (2008): Significance of flora with special reference to Pakistan. - Pakistan Journal of Botany 40(3): 967-971.

[3] Ali, S. I., Nasir, Y. J. (1989-1991): Flora of Pakistan. - Department of Botany, University of Karachi, Karachi and National Herbarium, Islamabad.

[4] Ali, S. I., Qaiser, M. (1995-2017): Flora of Pakistan. - Department of Botany, University of Karachi, Karachi.

[5] Badshah, L., Hussain, F., Sher, Z. (2013): Floristic inventory, ecological characteristics and biological spectrum of rangeland, District Tank, Pakistan. - Pakistan Journal of Botany 45(4): 1159-1168.

[6] Bhat, D. M., Murali, K. S. (2001): Phenology of understory species of tropical moist forest of Western Ghats region of Uttara Kannada district in South India. - Curr. Sci. 81: 799-805.

[7] Cornejo-Tenorio, G., Ibarra-Manríquez, G. (2007): Plant reproductive phenology in a temperate forest of the Monarch Butterfly Biosphere Reserve, Mexico. - Interciencia 32: 445-452.

[8] Durrani, M. J., Hussain, F., Rehman, S. U. (2005): Ecological characteristics of plants of Harboi rangeland, Kalat, Pakistan. - J. Trop. \& Sub Trop. Bot. 13(2): 130-138.

[9] Giusti, L., Slanis, A., Acenolaza, P. (1995): Phytosociology of alder woods (Alnus acuminate subspecies. acuminata) of Tucuman, Argentina. - Lilloa 38(2): 93-120.

[10] Gu, Z., Gu, L., Eils, R., Schlesner, M., Brors, B. (2014): Circlize implements and enhances circular visualization in R. Bioinformatics 30: 2811-2812.

[11] Hussain, F. (1989): Field and Laboratory Manual of Plant Ecology. - UGC, Islamabad.

[12] Ijaz, F. (2014): Biodiversity and traditional uses of plants of Sarban Hills, Abbottabad. M. Phil. Thesis Hazara University Mansehra, KP, Pakistan.

[13] Ijaz, F., Iqbal, Z., Alam, J., Khan, S. M., Afzal, A., Rahman, I., Afzal, M., Islam, M., Sohail (2015): Ethno medicinal study upon folk recipes against various human diseases in Sarban Hills, Abbottabad, Pakistan. - World Journal of Zoology 10: 41-46.

[14] Ijaz, F., Iqbal, Z., Rahman, I. U., Alam, J., Khan, S. M., Shah, G. M., Khan, K., Afzal, A. (2016): Investigation of traditional medicinal floral knowledge of Sarban Hills, Abbottabad, KP, Pakistan. - Journal of Ethnopharmacology 179: 208-233.

[15] Iqbal, M., Khan, S., Khan, M. A., Rahman, I. U., Abbas, Z., Zahidullah. (2015): Exploration and inventorying of weeds in wheat crop of the district Malakand, Pakistan. Pakistan Journal of Weed Science Research 21(3): 435-452.

[16] Jabeen, A., Khan, M. A., Ahmad, M., Zafar, M., Ahmad, F. (2009): Indigenous uses of economically important Flora of Margallah Hills National Park, Islamabad, Pakistan. African Journal of Biotechnology 8(5): 763-784.

[17] Khan, S. M. (2012): Plant communities and vegetation ecosystem services in the Naran Valley, Western Himalaya. - Doctoral dissertation, University of Leicester, UK.

[18] Khan, K. U, Shah, M., Ahmad, H., Ashraf, M., Rahman, I. U., Iqbal, Z., Khan, S. M., Majid, A. (2015a): Investigation of Traditional Veterinary Phytomedicines Used in Deosai Plateau, Pakistan. - Global Veterinary 15(4): 381-388. 
[19] Khan, S. M., Din, N. U., Ilyas, M., Sohail, Rahman, I. U., Ijaz, F., Iqbal, Z., Ali, Z. (2015b): Ethnobotanical study of some medicinal plants of Tehsil Kabal, Distrct Swat, KP, Pakistan. - Medicinal and Aromatic Plants 4: 189.

[20] Khattak, N. S., Nouroz, F., Rahman, I. U., Noreen. S. (2015): Ethno veterinary uses of medicinal plants of district Karak, Pakistan. - Journal of Ethnopharmacology 171: 273279.

[21] Malik, Z.H., Hussain, F. (1990): Phytosociology of some parts of Kotli Hills, Azad Kashmir. - Journal of Science Technology 14: 177-123.

[22] Manske, L. L. (2006): Westren Snowberry Biology. Annual Report. - North Dakota State University, Dickinson Research Extension Center, Dickinson, ND.

[23] Nasir, E., Ali, S. I. (1971-1989): Flora West of Pakistan. - Department of Botany, University of Karachi, Karachi and National Herbarium, Islamabad.

[24] Oosting, H. J. (1956): The Study of Plant Communities. 2nd Ed. - W. H. Freeman and Co., San Fransisco.

[25] Qureshi, R., Bhatti, G. R. (2008): Diversity of micro-habitats and their plant resources in Nara Desert, Pakistan. - Pakistan Journal of Botany 40(3): 979-992.

[26] Rahman, I. U., Ijaz, F., Afzal, A., Iqbal, Z., Ali, N., Khan, S. M. (2016a): Contributions to the phytotherapies of digestive disorders; Traditional knowledge and cultural drivers of Manoor Valley, Northern Pakistan. - Journal of Ethnopharmacology 192: 30-52.

[27] Rahman, I. U., Ijaz, F., Iqbal, Z., Afzal, A., Ali, N., Afzal, M., Khan, M. A., Muhammad, S., Qadir, G., Asif, M. (2016b): A novel survey of the ethno medicinal knowledge of dental problems in Manoor Valley (Northern Himalaya), Pakistan. - Journal of Ethnopharmacology 194C: 877-894.

[28] Rahman, I. U., Ijaz, F., Iqbal, Z., Afzal, A., Ali, N., Khan, M. A., Afzal, M., Muhammad, S., Qadir, G., Asif, M. (2016c): Graphical dataset on important medicinal plants used for curing dental issues in Manoor Valley, Mansehra, Pakistan. - Data in Brief 9: 1028-1033.

[29] Rahman, I. U., Afzal, A. F., Iqbal, Z. A., Ijaz, F., Ali, N., Asif, M., Alam, J., Majid, A., Bussmann, R. W., Hart, R. (2018a): First insights into the floristic diversity, biological spectra and phenology of Manoor Valley, Pakistan. - Pakistan Journal of Botany 50: 1113-24.

[30] Rahman, I. U., Afzal, A., Iqbal, Z., Ijaz, F., Ali, N., Shah, M., Ullah, S., Bussmann, R. W. (2018b): Historical perspectives of ethnobotany. - Clinics in Dermatology. https://doi.org/10.1016/j.clindermatol.2018.03.018.

[31] Rahman, I. U., Afzal, A., Iqbal, Z., Ijaz, F., Ali, N., Bussmann, R. W. (2018c): Traditional and ethnomedicinal dermatology practices in Pakistan. - Clinics in Dermatology 36(3): 310-319.

[32] Raunkiær, C. C. (1934): The Life Forms of Plants and Statistical Plants Geography. Clarendon Press, Oxford.

[33] Rokaya, M. B., Münzbergová, Z., Shrestha, M. R., Timsina, B. (2012): Distribution patterns of medicinal plants along an elevational gradient in central Himalaya, Nepal. Journal of Mountain Science 9(2): 201-213.

[34] Rokaya, M. B., Uprety, Y., Poudel, R. C., Timsina, B., Münzbergová, Z., Asselin, H., Tiwari, A., Shrestha, S. S., Sigdel, S. R. (2014): Traditional uses of medicinal plants in gastrointestinal disorders in Nepal. - Journal of Ethnopharmacology 158: 221-229.

[35] Safidkon, F., Kalvandi, R., Atri, M., Barazandeh, M. M. (2003): Contribution for the characterization of Thymus eriocalyx Chemotypes. - The International Magazine for Cosmetics and Fragrances.

[36] Shaheen, H., Qureshi, R. A. (2011): Vegetation types of Sheosar Lake and surrounding landscape in Deosai Plains of North Pakistan, Western Himalayas. - Journal of Medicinal Plant Research 5(4): 599-603.

[37] Shaheen, S., Iqbal, Z., Ijaz, F., Alam, J., Rahman, I. U. (2016): Floristic composition, biological spectrum and phenology of Tehsil Havelian, District Abbottabad, Pakistan. Pakistan Journal of Botany 48(5): 1849-1859. 
[38] Shimwell, D. W. (1971): The description and Classification of Vegetation. - Sedgwick \& Jackson, London.

[39] Singh, J. S., Singh, V. K. (1992): Phenology of seasonally dry tropical forest. - Current Sci. 63: 684-689.

[40] Vilela, A. A., Del Claro, V. T. S., Torezan-Silingardi, H. M., Del-Claro, K. (2017): Climate changes affecting biotic interactions, phenology, and reproductive success in a savanna community over a 10-year period. - Arthropod-Plant Interactions 12: 215-227.

[41] Walter, W., Hamilton, A. (1993): The vital wealth of plants. - Bates and Sons Ltd., UK.

[42] Zhang, J. T., Ru, W. M., Li, B. (2006): Relationships between vegetation and climate on the Loess Plateau in China. - Folia Geobot. 41: 151-163.

\section{APPENDIX}

Floristic composition, biological and leaf spectra, and phenological behaviour of the plant species of Manoor Valley, Pakistan

\begin{tabular}{|c|c|c|c|c|c|c|}
\hline \multirow{2}{*}{ S. No } & \multirow{2}{*}{$\begin{array}{l}\text { Family name/ } \\
\text { Scientific name }\end{array}$} & \multirow{2}{*}{ Habit } & \multicolumn{2}{|c|}{$\begin{array}{l}\text { Biological } \\
\text { spectrum }\end{array}$} & \multicolumn{2}{|c|}{ Phenology } \\
\hline & & & $\begin{array}{l}\text { Life } \\
\text { form }\end{array}$ & Leaf size & Flowering & Fruiting \\
\hline & Acanthaceae & & & & & \\
\hline 1 & Dicliptera bupleuroides Nees & $\mathrm{H}$ & Th & $\mathrm{N}$ & Sept & Feb \\
\hline 2 & $\begin{array}{l}\text { Justicia adhatoda } \mathrm{L} . \\
\text { Adiantaceae }\end{array}$ & S & NanP & $\mathrm{Me}$ & March & May \\
\hline 3 & Adiantum capillus-veneris $\mathrm{L}$. & $\mathrm{H}$ & G & $\mathrm{N}$ & July & Sept \\
\hline 4 & Adiantum indicum J. Ghatak & $\mathrm{H}$ & G & $\mathrm{Me}$ & July & Aug \\
\hline 5 & Adiantum venustum $\mathrm{D}$. Don & $\mathrm{H}$ & G & $\mathrm{N}$ & June & Aug \\
\hline 6 & $\begin{array}{c}\text { Asplenium adiantum-nigrum } \mathrm{L} . \\
\text { Adoxaceae }\end{array}$ & $\mathrm{H}$ & HemC & $\mathrm{N}$ & July & Sept \\
\hline 7 & Viburnum cotinifolium D. Don & S & NanP & $\mathrm{Ma}$ & March & May \\
\hline 8 & $\begin{array}{c}\text { Viburnum grandiflorum Wall. ex DC. } \\
\text { Amaranthaceae }\end{array}$ & $S$ & $\mathrm{NanP}$ & Ma & March & May \\
\hline 9 & Achyranthes aspera $\mathrm{L}$. & $\mathrm{H}$ & Th & $\mathrm{N}$ & May & July \\
\hline 10 & Achyranthes bidentata Blume & $\mathrm{H}$ & Th & Mi & Aug & Sept \\
\hline 11 & Amaranthus viridis $\mathrm{L}$. & $\mathrm{H}$ & Th & Mi & Aug & Sept \\
\hline 12 & $\begin{array}{c}\text { Celosia argentea } \mathrm{L} . \\
\text { Apiaceae }\end{array}$ & $\mathrm{H}$ & Th & $\mathrm{N}$ & Aug & Sept \\
\hline 13 & Aegopodium burttii Nasir & $\mathrm{H}$ & HemC & Mi & June & July \\
\hline 14 & Anthriscus nemorosa (M.Bieb.) Spreng. & $\mathrm{H}$ & Th & Mi & April & Aug \\
\hline 15 & Bupleurum nigrescens E. Nasir & $\mathrm{H}$ & Th & $\mathrm{N}$ & June & Sept \\
\hline 16 & Bupleurum gracillimum Klotzsch & $\mathrm{H}$ & Th & $\mathrm{N}$ & June & Sept \\
\hline 17 & Bupleurum longicaule Wall. ex DC. & $\mathrm{H}$ & Th & $\mathrm{N}$ & June & Sept \\
\hline 18 & Foeniculum vulgare Mill. & $\mathrm{H}$ & Th & $\mathrm{N}$ & July & Sept \\
\hline 19 & Heracleum candicans Wall. ex DC. & $\mathrm{H}$ & HemC & $\mathrm{L}$ & April & June \\
\hline 20 & Pimpinella stewartii (Dunn) Nasir & $\mathrm{H}$ & Th & $\mathrm{N}$ & July & Sept \\
\hline 21 & $\begin{array}{l}\text { Pleurospermum brunonis Benth. ex } \\
\text { C.B.Clarke }\end{array}$ & $\mathrm{H}$ & HemC & $\mathrm{L}$ & June & Aug \\
\hline
\end{tabular}




\section{Pleurospermum candollei Benth. ex C.B.Clarke}

Pleurospermum stellatum (D. Don) Benth. ex C.B. Clarke

Pleurospermum stylosum C.B. Clarke

Sanicula elata Buch.-Ham. ex D.Don

Seseli libanotis (L.) W.D.J.Koch .

Torilis japonica (Houtt.) DC.

Trachyspermum amii (L.) Sprague

\section{Araceae}

Arisaema flavum (Forsk.) Schott

Arisaema jacquemontii Blume

Sauromatum venosum (Dryand. ex Aiton) Kunth

\section{Araliaceae}

Aralia cachemirica Decne.

Hedera nepalensis K. Koch

\section{Asclepiadaceae}

Periploca aphylla Decne.

Vincetoxicum petrense (Hemsl. \& Lace) Rech. f.

\section{Asparagaceae}

Asparagus fiicinus Buch.-Ham. ex D. Don

\section{Asteraceae}

Achillea millefolium $\mathrm{L}$.

Ainsliaea aptera DC.

Anaphalis margaritacea (L.) Benth.

Anaphalis busua (Buch.-Ham.) DC.

Anaphalis contorta (D.Don) Hook.f.

Anaphalis nepalensis (Spreng.) Hand.Mazz.

Arctium minus (Hill) Benh.

Artemisia absinthium L.

Carpesium nepalense Less.

Chrysanthemum indicum $\mathrm{L}$.

Cichorium intybus $\mathrm{L}$.

Cirsium arvense (L.) Scop.

Cirsium falconeri (Hook.f.) Petr.

Conyza japonica (Thunb.) Less. ex Less.

Cyanthillium cinereum (L.) H.Rob.

Erigeron canadensis L.

Galinosoga parviflora Cav.

Gerbera gossypina (Royle) Beauverd

Helianthus annuus L.

Inula cuspidata (Wall. ex DC.)

.

$\mathrm{H}$

H

$\mathrm{H}$

$\mathrm{H}$

$\mathrm{H}$

$\mathrm{H}$

(1)

$\mathrm{H}$

$\mathrm{H}$

G

HemC

HemC

Th

Mi

HemC

N

$\mathrm{L}$

July

Aug

Th

Mi

Th

G

L

July

Aug

July

Aug

May

April

June

May

July

Aug

July

July

June

Sept

July

Aug

May

HemC

$\mathrm{L}$

May

June

Oct

April

S

NanP

Aph

May

July

June

July

May

June

May

Sept

Dec

June

Aug

Sept

Sept

Oct

Sept

Oct

May

Sept

June

Aug

Aug

Sept

Nov

Oct

Aug

Oct

Aug

Aug

July

Aug

Sept

June

June

Sept 


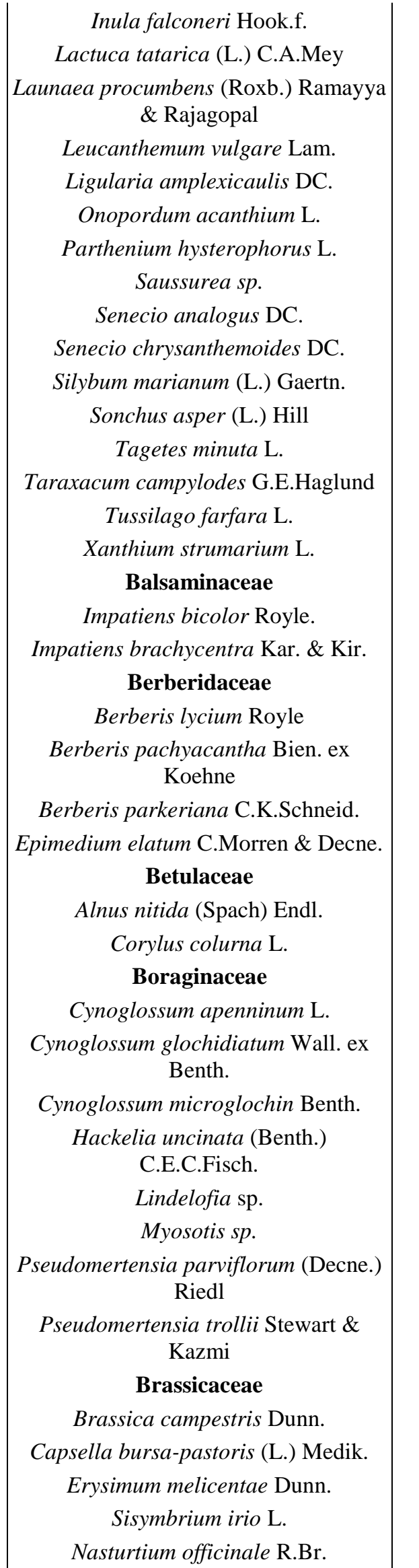

$\mathrm{H}$ Th $\mathrm{H}$

\begin{tabular}{c|}
$\mathrm{Me}$ \\
$\mathrm{Mi}$ \\
$\mathrm{Mi}$ \\
$\mathrm{L}$ \\
$\mathrm{Ma}$ \\
$\mathrm{Me}$
\end{tabular}

June

Oct $\mathrm{H} \quad \mathrm{Ch}$

$\mathrm{H}$

$\mathrm{H}$

$\mathrm{H}$

$\mathrm{H}$

$\mathrm{H}$

$\mathrm{H}$

$\mathrm{H}$

$\mathrm{H}$

HemC

HemC

Th

Th

Ch

Th

Th

HemC

Th

Th

Th

Th

$$
\text { N }
$$

\section{$\mathrm{Me}$}

Mi

$\mathrm{Me}$

$\mathrm{Me}$

Mi

Mi

Mi

$\mathrm{Me}$

$\mathrm{Me}$

$\mathrm{Me}$

May

July

March

May

June

Sept

May

April

Aug

All the year All the year

March

May

Aug

Sept

Oct

March

July

Nov

Sept

May

Oct

Feb

Aug

May

July

Sept

July

Sept

July

Sept

NanP

L

June

July

NanP

L

Feb

July

NanP

L

Feb

July

April

May

MesP

$\mathrm{Me}$

$\mathrm{Me}$

July

Sept

April

June

HemC $\quad \mathrm{N}$

June

Aug

June

Aug

June

Aug

June

Aug

June

May

Aug

July

May

July

HemC

N

HemC

N

May

Aug

June

July

Aug

Sept

June

April

July 


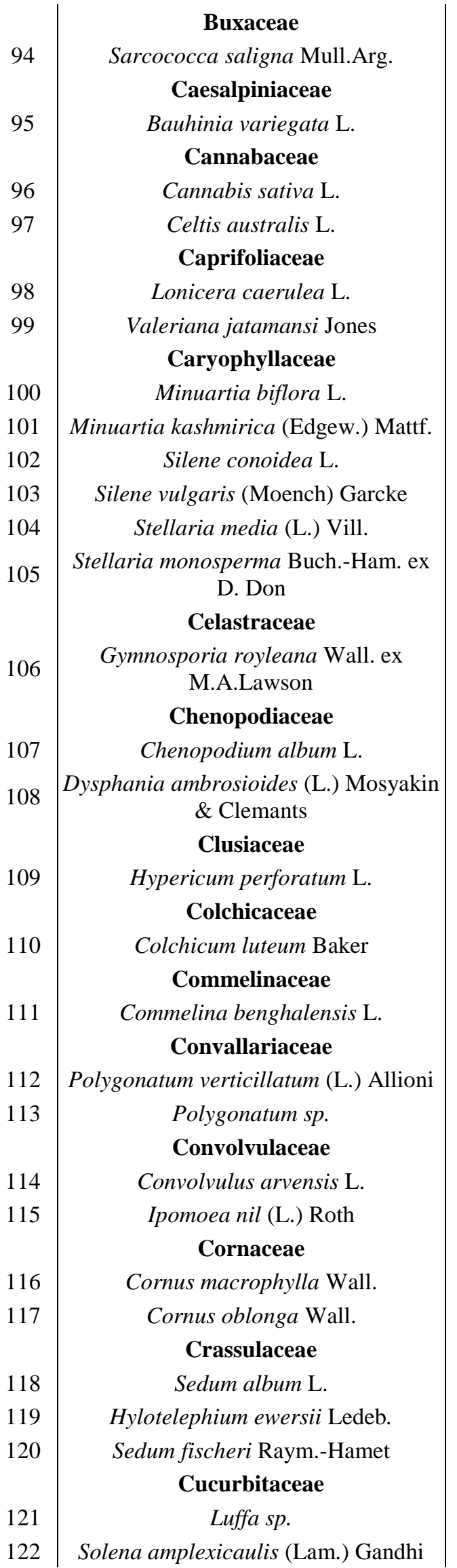

\begin{tabular}{|c|c|c|c|c|}
\hline $\mathrm{S}$ & NanP & $\mathrm{Mi}$ & Dec & March \\
\hline $\mathrm{T}$ & MicP & $\mathrm{Me}$ & March & April \\
\hline $\mathrm{H}$ & Th & $\mathrm{Mi}$ & July & Sept \\
\hline $\mathrm{T}$ & MesP & $\mathrm{Ma}$ & May & Aug \\
\hline $\mathrm{S}$ & NanP & $\mathrm{Mi}$ & March & May \\
\hline $\mathrm{H}$ & G & $\mathrm{Me}$ & May & July \\
\hline $\mathrm{H}$ & HemC & $\mathrm{L}$ & Aug & Sept \\
\hline $\mathrm{H}$ & $\mathrm{Ch}$ & $\mathrm{L}$ & July & Sept \\
\hline $\mathrm{H}$ & Th & $\mathrm{N}$ & April & May \\
\hline $\mathrm{H}$ & Th & $\mathrm{N}$ & July & Sept \\
\hline $\mathrm{H}$ & Th & $\mathrm{N}$ & Oct & Nov \\
\hline $\mathrm{H}$ & Th & $\mathrm{Mi}$ & Sept & Oct \\
\hline S & NanP & $\mathrm{Mi}$ & March & May \\
\hline $\mathrm{H}$ & HemC & $\mathrm{N}$ & June & Sept \\
\hline $\mathrm{H}$ & Th & $\mathrm{Mi}$ & May & June \\
\hline $\mathrm{H}$ & $\mathrm{Ch}$ & $\mathrm{N}$ & July & Sept \\
\hline $\mathrm{H}$ & G & $\mathrm{N}$ & July & Sept \\
\hline $\mathrm{H}$ & $\mathrm{Ch}$ & $\mathrm{N}$ & Sept & Oct \\
\hline $\mathrm{H}$ & Th & $\mathrm{N}$ & June & Aug \\
\hline $\mathrm{H}$ & Th & $\mathrm{Mi}$ & May & July \\
\hline $\mathrm{H}$ & HemC & $\mathrm{N}$ & May & July \\
\hline $\mathrm{H}$ & Th & $\mathrm{Mi}$ & May & July \\
\hline $\mathrm{T}$ & MesP & $\mathrm{Ma}$ & March & May \\
\hline $\mathrm{T}$ & MesP & $\mathrm{Me}$ & June & Sept \\
\hline $\mathrm{H}$ & $\mathrm{Ch}$ & $\mathrm{N}$ & July & Oct \\
\hline $\mathrm{H}$ & $\mathrm{Ch}$ & $\mathrm{Mi}$ & Oct & Nov \\
\hline $\mathrm{H}$ & Th & $\mathrm{L}$ & July & Sept \\
\hline $\mathrm{H}$ & $\mathrm{Th}$ & $\mathrm{Mi}$ & June & July \\
\hline $\mathrm{H}$ & Th & $\mathrm{Mi}$ & Aug & Oct \\
\hline
\end{tabular}




\section{Cupressaceae}

Juniperus communis L.

Juniperus squamata Buch.-Ham. ex D.Don

Juniperus excelsa M.Bieb.

Cuscutaceae

Cuscuta reflexa Roxb.

Cyperaceae

Carex sp.

Cyperus rotundus $\mathrm{L}$.

Cyperus odoratus L.

Dioscoreaceae

Dioscorea deltoidea Wall. ex Griseb.

Dipsacaceae

Dipsacus inermis Wall. in Roxb.

Dryopteridaceae

Dryopteris wallichiana (Spreng.) Hyl.

Dennstaedtiaceae

Pteridium aquilinum (L.) Kuhn

Ebenaceae

Diospyros lotus L.

Eleagnaceae

Elaeagnus umbellata Thunb.

Ephedraceae

Ephedra girardiana Wall. ex. Stapf

Equisetaceae

Equisetum arvense $\mathrm{L}$

\section{Ericaceae}

Cassiope fastigiata (Wall.) D.Don

Lyonia ovalifolia (Wall.) Drude

Rhododendron arboreum $\mathrm{Sm}$.

Rhododendron hypenanthum Balf. f.

Euphorbiaceae

Euphorbia helioscopia L.

Euphorbia prostrata Ait.

Euphorbia hirta L.

Euphorbia serpens Kunth

Euphorbia wallichii Hook. f.

Ricinus communis $\mathrm{L}$.

Fagaceae

Castanea sativa Mill.

Quercus incana Bartram

Fumaricaceae

Fumaria indica (Hausskn) Pugsley

Gentianaceae

Gentianodes clarkei (Kusn.) Omer

P

$\mathrm{H}$

$\mathrm{H}$

$\mathrm{H}$

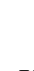

$\mathrm{H}$

$\mathrm{H}$

$\mathrm{H}$

$\mathrm{T}$

S

$\mathrm{S}$

$\mathrm{H}$

S

$\mathrm{T}$

$\mathrm{S}$

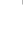

$\mathrm{H}$

$\mathrm{H}$

$\mathrm{H}$
$\mathrm{H}$

$\mathrm{H}$

$\mathrm{H}$

$\mathrm{H}$

S

$\mathrm{T}$

$\mathrm{T}$
$\mathrm{T}$

$\mathrm{H}$

H

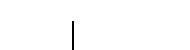
NanP

NanP

NanP

$P p$

p

Aph

Aug

June

July

Sept

Oct

Sept

March

May

Aug

Oct

Aug

Sept

Nov

Dec

HemC

Mi

May

July

July

Aug

Aug

Nov

G

Ma

MicP

Ma

June

Nov

April

May

Aug

Oct

April

May

May

July

May

Oct

April

May

April

May

May

June

All the year All the year

$\mathrm{Ch}$

$\mathrm{N}$

Aug

Oct

June

July

Aug

Oct

June

Oct

May

July

May

July

April

June

Aug

Oct 


\begin{tabular}{|c|c|c|c|c|}
\hline $\begin{array}{c}\text { Lomatogonium spathulatum (A. Kern.) } \\
\text { Fernald }\end{array}$ & $\mathrm{H}$ & Th & $\mathrm{N}$ & April \\
\hline Swertia paniculata Wall. & $\mathrm{H}$ & Th & $\mathrm{L}$ & July \\
\hline $\begin{array}{c}\text { Swertia ciliata (D. Don ex G. Don) B.L. } \\
\text { Burtt }\end{array}$ & $\mathrm{H}$ & Th & $\mathrm{L}$ & July \\
\hline $\begin{array}{c}\text { Swertia cordata (Wall. ex G. Don) C.B. } \\
\text { Clarke }\end{array}$ & $\mathrm{H}$ & Th & $\mathrm{L}$ & July \\
\hline Geraniaceae & & & & \\
\hline Geranium nepalense Sweet. & $\mathrm{H}$ & $\mathrm{Ch}$ & Mi & July \\
\hline $\begin{array}{l}\text { Geranium wallichianum D.Don ex } \\
\text { Sweet }\end{array}$ & $\mathrm{H}$ & $\mathrm{Ch}$ & Mi & July \\
\hline $\begin{array}{c}\text { Hamamelidaceae } \\
\text { Parrotiopsis jacquemontiana (Decne.) } \\
\text { Rehder }\end{array}$ & $\mathrm{S}$ & $\mathrm{NanP}$ & $\mathrm{Mi}$ & June \\
\hline $\begin{array}{c}\text { Hippocastanaceae } \\
\text { Aesculus indica (Wall. ex Camb.) } \\
\text { Hook. }\end{array}$ & $\mathrm{T}$ & $\mathrm{MegP}$ & $\mathrm{Me}$ & July \\
\hline $\begin{array}{l}\text { Hippolytia dolichophylla (Kitam.) } \\
\text { K.Bremer \& Humphries }\end{array}$ & $\mathrm{H}$ & HemC & $\mathrm{Me}$ & May \\
\hline Juglandaceae & & & & \\
\hline $\begin{array}{l}\text { Juglans regia L. } \\
\text { Juncaceae }\end{array}$ & $\mathrm{T}$ & $\mathrm{MegP}$ & $\mathrm{Ma}$ & July \\
\hline $\begin{array}{c}\text { Juncus sp. } \\
\text { Lamiaceae }\end{array}$ & $\mathrm{H}$ & G & $\mathrm{N}$ & Sept \\
\hline Ajuga integrifolia Buch.-Ham. & $\mathrm{H}$ & HemC & Mi & May \\
\hline $\begin{array}{l}\text { Calamintha umbrosa (M.Bieb.) } \\
\text { Rchb.Benth.) Hedge }\end{array}$ & $\mathrm{H}$ & Th & $\mathrm{N}$ & July \\
\hline Clinopodium vulgare $\mathrm{L}$. & $\mathrm{H}$ & HemC & Mi & April \\
\hline Colebrookea oppositifolia Sm. & $\mathrm{S}$ & NanP & $\mathrm{L}$ & July \\
\hline Dracocephalum nutans $\mathrm{L}$. & $\mathrm{H}$ & Th & $\mathrm{N}$ & July \\
\hline Elsholtzia ciliata (Thunb.) Hyl. & $\mathrm{H}$ & Th & $\mathrm{N}$ & July \\
\hline Isodon rugosus (Wall. ex Benth.) Codd & $\mathrm{S}$ & $\mathrm{NanP}$ & Mi & May \\
\hline Lamium album $\mathrm{L}$. & $\mathrm{H}$ & Th & Mi & July \\
\hline Lamium amplexicaule $\mathrm{L}$. & $\mathrm{H}$ & Th & Mi & July \\
\hline Mentha piperita $\mathrm{L}$. & $\mathrm{H}$ & $\mathrm{HemC}$ & $\mathrm{N}$ & June \\
\hline Mentha royleana Wall. ex Benth. & $\mathrm{H}$ & HemC & Mi & June \\
\hline Micromeria biflora (Ham.) Bth. & $\mathrm{H}$ & $\mathrm{Ch}$ & $\mathrm{L}$ & April \\
\hline Nepeta graciliflora Benth. & $\mathrm{H}$ & Th & Mi & July \\
\hline Nepeta laevigata (D. Don) Hand.- Mazz & $\mathrm{H}$ & Th & Mi & July \\
\hline Origanum majorana $\mathrm{L}$. & $\mathrm{H}$ & Th & $\mathrm{N}$ & June \\
\hline Origanum vulgare $\mathrm{L}$. & $\mathrm{H}$ & Th & $\mathrm{N}$ & July \\
\hline Prunella vulgaris $\mathrm{L}$. & $\mathrm{H}$ & $\mathrm{HemC}$ & $\mathrm{N}$ & Sept \\
\hline $\begin{array}{c}\text { Rydingia limbata (Benth.) Scheen \& } \\
\text { V.A. Albert }\end{array}$ & S & $\mathrm{NanP}$ & $\mathrm{L}$ & July \\
\hline Salvia lanata Roxb. & $\mathrm{H}$ & $\mathrm{Ch}$ & $\mathrm{Mi}$ & April \\
\hline Salvia moorcroftiana Wall. ex. Benth. & $\mathrm{S}$ & Th & $\mathrm{Me}$ & March \\
\hline Salvia nubicola Wall. ex Sweet & $\mathrm{H}$ & Th & $\mathrm{Me}$ & June \\
\hline Thymus linearis Benth. & $\mathrm{H}$ & HemC & $\mathrm{N}$ & July \\
\hline
\end{tabular}


Liliaceae Gagea lutea (L.) Ker Gawl. Linaceae Reinwardtia trigyna Planch. Lythraceae Punica granatum $\mathrm{L}$.

Malvaceae

Alcea rosea $\mathrm{L}$.

Grewia optiva J.R.Drumm. ex Burret

Lavatera cachemiriana Camb. in Jacq.

Malva parviflora $\mathrm{L}$.

Malva neglecta Wallr.

Malvastrum coromandelianum (L.)

$$
\text { Garcke }
$$

Sida cordata (Burm.f.) Borss.Waalk.

\section{Meliaceae}

Melia azedarach L.

Mimosaceae

Acacia modesta Wall. Acacia nilotica (L.) Delile

Moraceae

Ficus carica $\mathrm{L}$.

Oleaceae

Fraxinus hookeri Wenz.

Fraxinus xanthoxyloides (G. Don) DC

\section{Jasminum humile L.}

Jasminum sambac (L.) Aiton

Olea ferruginea Wall. ex Aitch.

Onagraceae

Circaea cordata Royle.

Circaea alpina $\mathrm{L}$

Epilobium hirsutum L.

Epilobium latifolium $\mathrm{L}$.

Oenothera rosea L. Her ex Aiton

Orchidaceae

Spiranthes sinensis (Pers.) Ames

Orobanchaceae

Euphrasia himalayica Wetts.

Pedicularis punctata Decne.

\section{Oxalidaceae}

Oxalis corniculata $\mathrm{L}$.

Papaveraceae

Corydalis cornuta Royle

Corydalis carinata Lidén \& Z.Y.Su

Corydalis virginea Lidén \& Z.Y.Su

Papilionaceae

Astragalus grahamianus Benth.

\begin{tabular}{|c|c|c|c|}
\hline $\mathrm{H}$ & G & $\mathrm{N}$ & Mar \\
\hline $\mathrm{H}$ & $\mathrm{Ch}$ & $\mathrm{L}$ & June \\
\hline $\mathrm{S}$ & NanP & Mi & May \\
\hline $\mathrm{H}$ & HemC & $\mathrm{Ma}$ & April \\
\hline $\mathrm{T}$ & MesP & $\mathrm{N}$ & April \\
\hline $\mathrm{H}$ & HemC & $\mathrm{Me}$ & May \\
\hline $\mathrm{H}$ & HemC & $\mathrm{Mi}$ & April \\
\hline $\mathrm{H}$ & HemC & Mi & May \\
\hline $\mathrm{H}$ & HemC & $\mathrm{N}$ & April \\
\hline $\mathrm{H}$ & HemC & $\mathrm{N}$ & May \\
\hline $\mathrm{T}$ & MesP & $\mathrm{Me}$ & April \\
\hline $\mathrm{T}$ & $\mathrm{MicP}$ & $\mathrm{L}$ & March \\
\hline $\mathrm{T}$ & MesP & $\mathrm{L}$ & April \\
\hline $\mathrm{T}$ & $\mathrm{MicP}$ & $\mathrm{Me}$ & May \\
\hline $\mathrm{T}$ & $\mathrm{MicP}$ & $\mathrm{Me}$ & April \\
\hline $\mathrm{T}$ & $\mathrm{MicP}$ & $\mathrm{Me}$ & May \\
\hline $\mathrm{S}$ & NanP & $\mathrm{N}$ & June \\
\hline S & NanP & $\mathrm{N}$ & June \\
\hline $\mathrm{T}$ & MesP & Mi & April \\
\hline $\mathrm{H}$ & Th & $\mathrm{Me}$ & June \\
\hline $\mathrm{H}$ & Th & $\mathrm{Mi}$ & June \\
\hline $\mathrm{H}$ & $\mathrm{Ch}$ & $\mathrm{Mi}$ & May \\
\hline $\mathrm{H}$ & HemC & $\mathrm{L}$ & July \\
\hline $\mathrm{H}$ & Th & $\mathrm{N}$ & June \\
\hline $\mathrm{H}$ & G & $\mathrm{N}$ & June \\
\hline $\mathrm{H}$ & Th & $\mathrm{L}$ & July \\
\hline $\mathrm{H}$ & HemC & $\mathrm{N}$ & July \\
\hline $\mathrm{H}$ & HemC & $\mathrm{N}$ & May \\
\hline $\mathrm{H}$ & Th & $\mathrm{L}$ & Oct \\
\hline $\mathrm{H}$ & Th & $\mathrm{L}$ & July \\
\hline $\mathrm{H}$ & HemC & $\mathrm{N}$ & March \\
\hline$S$ & $\mathrm{Ch}$ & $\mathrm{L}$ & Sept \\
\hline
\end{tabular}




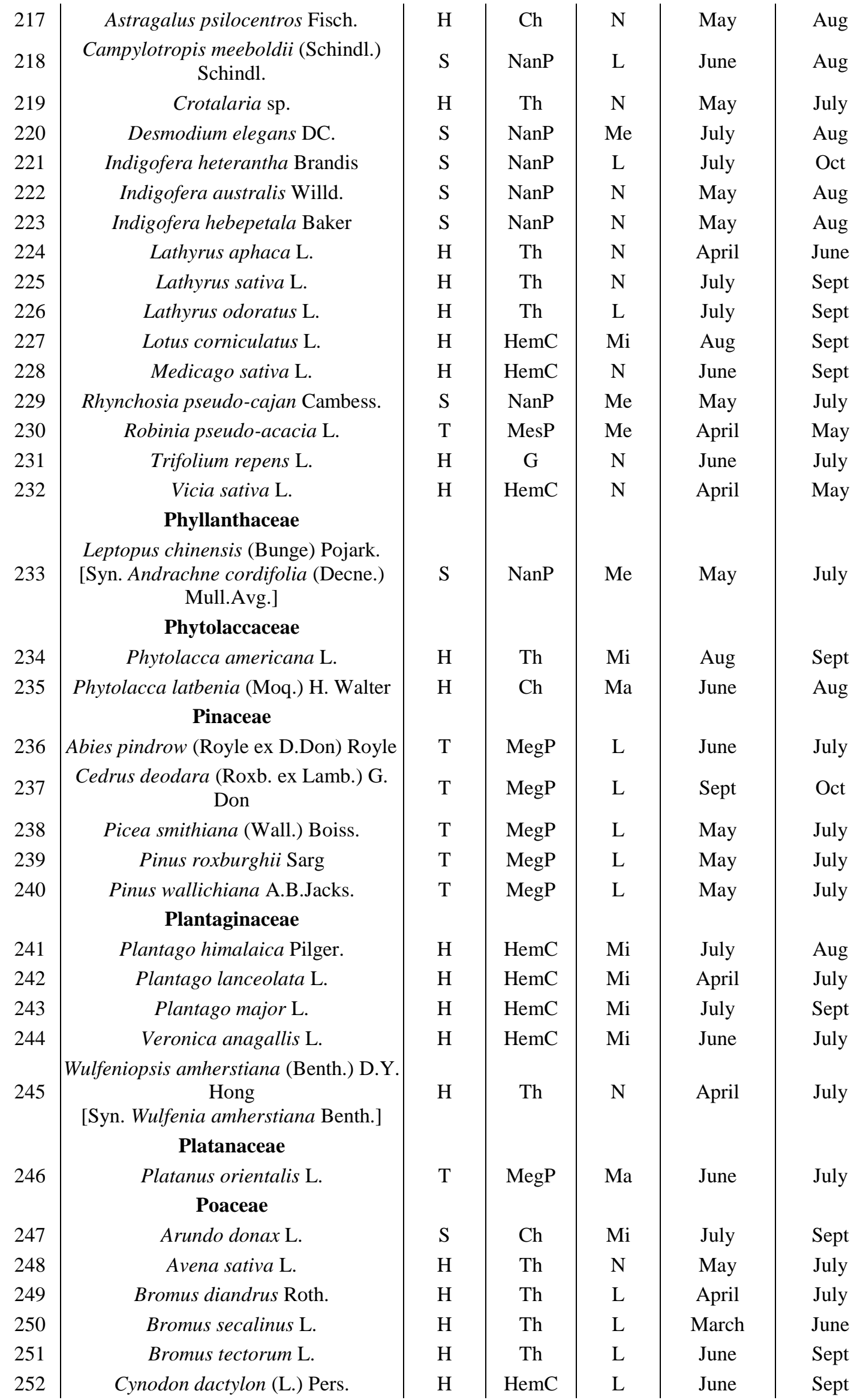




\begin{tabular}{|c|c|c|c|c|c|}
\hline 253 & Dactylis glomerata L. & $\mathrm{H}$ & HemC & $\mathrm{N}$ & July \\
\hline 254 & Paspalum dilatatun Poir. & $\mathrm{H}$ & HemC & $\mathrm{N}$ & April \\
\hline 255 & Pennisetum orientale Rich. & $\mathrm{H}$ & HemC & $\mathrm{L}$ & June \\
\hline 256 & Phragmites altissimus (Benth.) Mabille & $\mathrm{H}$ & $\mathrm{Th}$ & $\mathrm{Mi}$ & Aug \\
\hline 257 & $\begin{array}{l}\text { Piptatherum aequiglume (Duthie ex } \\
\text { Hook.f.) Roshev. }\end{array}$ & $\mathrm{H}$ & $\mathrm{Th}$ & $\mathrm{L}$ & May \\
\hline 258 & Poa alpina $\mathrm{L}$. & $\mathrm{H}$ & HemC & $\mathrm{N}$ & June \\
\hline 259 & Poa falconeri Hook. f. & $\mathrm{H}$ & HemC & $\mathrm{L}$ & June \\
\hline 260 & Poа аппиа $\mathrm{L}$. & $\mathrm{H}$ & HemC & $\mathrm{L}$ & May \\
\hline 261 & Poa infirma Kunth & $\mathrm{H}$ & HemC & $\mathrm{L}$ & April \\
\hline 262 & Saccharum spontaneum L. & $\mathrm{H}$ & HemC & $\mathrm{N}$ & June \\
\hline 263 & Schismus arabicus Nees. & $\mathrm{H}$ & HemC & $\mathrm{L}$ & June \\
\hline 264 & Sorghum halepense (L.) Pers. & $\mathrm{H}$ & HemC & $\mathrm{N}$ & May \\
\hline 265 & Sporobolus diandrus (Retz.) P.Beauv. & $\mathrm{H}$ & HemC & $\mathrm{L}$ & Sept \\
\hline 266 & $\begin{array}{c}\text { Urochloa panicoides P.Beauv. } \\
\text { Polygonaceae }\end{array}$ & $\mathrm{H}$ & HemC & $\mathrm{N}$ & July \\
\hline 267 & Bistorta affinis (D.Don) Green & $\mathrm{H}$ & $\mathrm{Ch}$ & $\mathrm{Mi}$ & July \\
\hline 268 & Bistorta amplexicaulis (D.Don) Greene & $\mathrm{H}$ & $\mathrm{Ch}$ & $\mathrm{Mi}$ & July \\
\hline 269 & Fagopyrum tataricum (L.) Gaertn. & $\mathrm{H}$ & $\mathrm{Th}$ & $\mathrm{Ma}$ & July \\
\hline 270 & Oxyria digyna (L.) Hill & $\mathrm{H}$ & $\mathrm{Ch}$ & Mi & June \\
\hline 271 & $\begin{array}{c}\text { Persicaria capitata (Buch.-Ham. ex } \\
\text { D.Don) H.Gross }\end{array}$ & $\mathrm{H}$ & $\mathrm{Th}$ & $\mathrm{L}$ & June \\
\hline 272 & Polygonum plebeium $\mathrm{R} . \mathrm{Br}$. & $\mathrm{H}$ & HemC & $\mathrm{Mi}$ & July \\
\hline 273 & Rheum australe D. Don & $\mathrm{H}$ & $\mathrm{Ch}$ & $\mathrm{Me}$ & June \\
\hline 274 & Rumex dentatus $\mathrm{L}$. & $\mathrm{H}$ & $\mathrm{Th}$ & $\mathrm{Me}$ & Aug \\
\hline 275 & Rumex hastatus D. Don & $\mathrm{H}$ & $\mathrm{Th}$ & $\mathrm{N}$ & June \\
\hline 276 & $\begin{array}{c}\text { Rumex nepalensis Sprenge } \\
\text { Portulacaceae }\end{array}$ & $\mathrm{H}$ & $\mathrm{Th}$ & $\mathrm{Me}$ & July \\
\hline 277 & $\begin{array}{l}\text { Portulaca oleracea L. } \\
\text { Primulaceae }\end{array}$ & $\mathrm{H}$ & Th & $\mathrm{N}$ & May \\
\hline 278 & Anagallis arvensis L. & $\mathrm{H}$ & $\mathrm{Ch}$ & $\mathrm{N}$ & May \\
\hline 279 & $\begin{array}{c}\text { Androsace hazarica R.R. Stewart ex } \\
\text { Y.Nasir }\end{array}$ & $\mathrm{H}$ & $\mathrm{Th}$ & $\mathrm{Mi}$ & May \\
\hline 280 & Androsace rotundifolia Hardw. & $\mathrm{H}$ & Th & $\mathrm{Mi}$ & June \\
\hline 281 & Primula rosea Y.J. Nasir & $\mathrm{H}$ & $\mathrm{G}$ & $\mathrm{Mi}$ & Oct \\
\hline 282 & $\begin{array}{c}\text { Primula hazarica } \text { Duthie } \\
\text { Pteridaceae }\end{array}$ & $\mathrm{H}$ & HemC & $\mathrm{Mi}$ & July \\
\hline 283 & Onychium contiguum C.Hope & $\mathrm{H}$ & G & $\mathrm{Me}$ & June \\
\hline 284 & $\begin{array}{l}\text { Pteris vittata } \mathrm{L} \text {. } \\
\text { Ranunculaceae }\end{array}$ & $\mathrm{H}$ & G & $\mathrm{Me}$ & June \\
\hline 285 & Aconitum heterophyllum Wall. ex Royle & $\mathrm{H}$ & HemC & $\mathrm{Me}$ & June \\
\hline 286 & Anemone obtusiloba D.Don & $\mathrm{H}$ & HemC & $\mathrm{L}$ & May \\
\hline 287 & Aquilegia pubiflora Wall. ex Royle & $\mathrm{H}$ & HemC & $\mathrm{Mi}$ & June \\
\hline 288 & $\begin{array}{c}\text { Caltha palustris var. alba (Cambess) } \\
\text { Hook.f. \& Thomson }\end{array}$ & $\mathrm{H}$ & $\mathrm{Th}$ & $\mathrm{Ma}$ & July \\
\hline 289 & Clematis grata Wall. & $\mathrm{H}$ & $\mathrm{L}$ & $\mathrm{Mi}$ & July \\
\hline 290 & Delphinium cashmerianum Royle & $\mathrm{H}$ & $\mathrm{Th}$ & Mi & Aug \\
\hline
\end{tabular}




\begin{tabular}{|c|c|c|c|c|c|}
\hline 291 & $\begin{array}{l}\text { Ranunculus laetus Wall. ex Hook. f. \& } \\
\text { J.W. Thompson }\end{array}$ & $\mathrm{H}$ & HemC & $\mathrm{Me}$ & June \\
\hline 292 & Ranunculus muricatus L. & $\mathrm{H}$ & HemC & $\mathrm{Ma}$ & June \\
\hline 293 & $\begin{array}{c}\text { Thalictrum pedunculatum Edgew. } \\
\text { Rhamnaceae }\end{array}$ & $\mathrm{H}$ & HemC & $\mathrm{N}$ & June \\
\hline 294 & Rhamnus purpurea Edgew. & $\mathrm{T}$ & $\mathrm{NanP}$ & $\mathrm{Mi}$ & May \\
\hline 295 & $\begin{array}{c}\text { Ziziphus undulata Reissek } \\
\text { Rosaceae }\end{array}$ & $\mathrm{S}$ & $\mathrm{NanP}$ & $\mathrm{Mi}$ & June \\
\hline 296 & Alchemilla cashmeriana Rothum. & $\mathrm{H}$ & HemC & $\mathrm{N}$ & June \\
\hline 297 & Cotoneaster acuminatus Wall. ex Lindl. & $\mathrm{S}$ & $\mathrm{NanP}$ & $\mathrm{N}$ & June \\
\hline 298 & $\begin{array}{c}\text { Cotoneaster microphyllus Wall. ex } \\
\text { Lindl }\end{array}$ & $\mathrm{S}$ & $\mathrm{NanP}$ & $\mathrm{N}$ & May \\
\hline 299 & Duchesnea indica (Andx) Fake. & $\mathrm{H}$ & HemC & $\mathrm{N}$ & April \\
\hline 300 & $\begin{array}{l}\text { Filipendula vestita (Wall. ex G. Don.) } \\
\text { Maxim. }\end{array}$ & $\mathrm{H}$ & Th & $\mathrm{Me}$ & June \\
\hline 301 & $\begin{array}{l}\text { Fragaria nubicola (Hook. f.) Lindl. ex } \\
\text { Lacaita }\end{array}$ & $\mathrm{H}$ & HemC & $\mathrm{N}$ & May \\
\hline 302 & Geum elatum Wall. ex G.Don & $\mathrm{H}$ & HemC & $\mathrm{N}$ & Aug \\
\hline 303 & Malus domestica Borkh. & $\mathrm{T}$ & MicP & $\mathrm{Me}$ & April \\
\hline 304 & Potentilla anserina $\mathrm{L}$. & $\mathrm{H}$ & HemC & $\mathrm{L}$ & June \\
\hline 305 & Potentilla argentea $\mathrm{L}$. & $\mathrm{H}$ & HemC & $\mathrm{L}$ & June \\
\hline 306 & Potentilla napalensis Hook. & $\mathrm{H}$ & HemC & $\mathrm{Mi}$ & June \\
\hline 307 & Prunus cornuta (Wall.ex Royle) Steud & $\mathrm{T}$ & MesP & $\mathrm{Me}$ & May \\
\hline 308 & Prunus armeniaca $\mathrm{L}$. & $\mathrm{T}$ & MesP & $\mathrm{Mi}$ & March \\
\hline 309 & Prunus domestica $\mathrm{L}$. & $\mathrm{T}$ & MesP & $\mathrm{Me}$ & May \\
\hline 310 & Pyrus pashia Buch.-Ham. ex D.Don & $\mathrm{T}$ & MesP & $\mathrm{Mi}$ & April \\
\hline 311 & Rosa webbiana Wall. ex. Royle & $\mathrm{S}$ & $\mathrm{NanP}$ & $\mathrm{N}$ & May \\
\hline 312 & Rosa brunonii Lindl. & $\mathrm{S}$ & $\mathrm{NanP}$ & $\mathrm{Mi}$ & June \\
\hline 313 & Rubus fruticosus Agg. & $\mathrm{S}$ & $\mathrm{NanP}$ & $\mathrm{Mi}$ & July \\
\hline 314 & Rubus sanctus Schreber & $\mathrm{S}$ & $\mathrm{NanP}$ & $\mathrm{Mi}$ & July \\
\hline 315 & Sibbaldia procumbens L. & $\mathrm{H}$ & HemC & $\mathrm{N}$ & Oct \\
\hline 316 & Sorbaria tomentosa (Lindl.) Rehder & $\mathrm{S}$ & NanP & $\mathrm{Me}$ & June \\
\hline 317 & Sorbus tomentosa Hedl. & $\mathrm{S}$ & NanP & $\mathrm{Me}$ & July \\
\hline 318 & Spiraea vaccinifolia D.Don & $\mathrm{S}$ & $\mathrm{NanP}$ & $\mathrm{Mi}$ & April \\
\hline 319 & $\begin{array}{c}\text { Spiraea affinis R.Parker } \\
\text { Rubiaceae }\end{array}$ & $\mathrm{S}$ & $\mathrm{NanP}$ & $\mathrm{Me}$ & July \\
\hline 320 & Galium aparine $\mathrm{L}$. & $\mathrm{H}$ & $\mathrm{Th}$ & $\mathrm{L}$ & July \\
\hline 321 & Galium asparagifolium Boiss. \& Heldr. & $\mathrm{H}$ & $\mathrm{Th}$ & $\mathrm{L}$ & May \\
\hline 322 & Galium elagans Wall. & $\mathrm{H}$ & $\mathrm{Th}$ & $\mathrm{N}$ & July \\
\hline 323 & $\begin{array}{l}\text { Himalrandia tetrasperma (Wall. ex } \\
\text { Roxb.) T.Yamaz. }\end{array}$ & $\mathrm{H}$ & HemC & $\mathrm{Mi}$ & June \\
\hline 324 & $\begin{array}{c}\text { Leptodermis virgata Edgew. ex Hook.f. } \\
\text { Rutaceae }\end{array}$ & $\mathrm{H}$ & $\mathrm{Ch}$ & $\mathrm{N}$ & May \\
\hline 325 & $\begin{array}{l}\text { Zanthoxylum armatum DC. } \\
\text { Salicaceae }\end{array}$ & $\mathrm{S}$ & MicP & $\mathrm{Mi}$ & July \\
\hline 326 & Populus alba $\mathrm{L}$. & $\mathrm{T}$ & MesP & $\mathrm{Ma}$ & June \\
\hline 327 & Populus ciliata Wall. ex Royle & $\mathrm{T}$ & MesP & $\mathrm{Ma}$ & May \\
\hline
\end{tabular}




\begin{tabular}{|c|c|c|c|c|c|c|}
\hline 328 & Populus nigra L. & $\mathrm{T}$ & MesP & $\mathrm{Ma}$ & June & Aug \\
\hline 329 & Salix alba $\mathrm{L}$. & $\mathrm{T}$ & MesP & $\mathrm{Mi}$ & June & Oct \\
\hline 330 & $\begin{array}{l}\text { Salix denticulata subsp. hazarica (R. } \\
\text { Parker) Ali }\end{array}$ & $\mathrm{T}$ & MesP & $\mathrm{Mi}$ & June & Oct \\
\hline 331 & $\begin{array}{c}\text { Salix tetrasperma Roxb. } \\
\text { Sambucaceae }\end{array}$ & $\mathrm{T}$ & MesP & $\mathrm{Mi}$ & June & Oct \\
\hline 332 & $\begin{array}{c}\text { Sambucus wightiana Wall. ex Wight } \& \\
\text { Arn } \\
\text { Sapindaceae }\end{array}$ & $\mathrm{S}$ & $\mathrm{Th}$ & $\mathrm{Me}$ & July & Sept \\
\hline 333 & Acer caesium Wall. ex Brandis & $\mathrm{T}$ & $\mathrm{MegP}$ & $\mathrm{L}$ & April & July \\
\hline 334 & $\begin{array}{c}\text { Dodonaea viscosa (L.) Jacq. } \\
\text { Saxifragaceae }\end{array}$ & $\mathrm{S}$ & NanP & $\mathrm{Me}$ & April & Aug \\
\hline 335 & Bergenia ciliata (Haw.) Sternb. & $\mathrm{H}$ & $\mathrm{Ch}$ & $\mathrm{Me}$ & Aug & Oct \\
\hline 336 & $\begin{array}{c}\text { Bergenia stracheyi Hook.f \& thomes. } \\
\text { Scrophulariaceae }\end{array}$ & $\mathrm{H}$ & HemC & $\mathrm{Me}$ & Sept & Oct \\
\hline 337 & $\begin{array}{l}\text { Verbascum thapsus L. } \\
\text { Simaroubaceae }\end{array}$ & $\mathrm{H}$ & $\mathrm{Th}$ & $\mathrm{Me}$ & July & Aug \\
\hline 338 & $\begin{array}{c}\text { Ailanthus altissima (Mill.) Swingle } \\
\text { Smilacaceae }\end{array}$ & $\mathrm{T}$ & MesP & $\mathrm{Mi}$ & May & July \\
\hline 339 & $\begin{array}{l}\text { Smilax glaucophylla Koltzsch } \\
\text { Solanaceae }\end{array}$ & $\mathrm{H}$ & $\mathrm{L}$ & $\mathrm{Mi}$ & June & Aug \\
\hline 340 & Hyoscyamus niger L. & $\mathrm{H}$ & $\mathrm{Th}$ & $\mathrm{Me}$ & July & Sept \\
\hline 341 & Solanum nigrum $\mathrm{L}$. & $\mathrm{H}$ & $\mathrm{Th}$ & $\mathrm{Mi}$ & July & Oct \\
\hline 342 & Solanum surattense Burm F. & $\mathrm{H}$ & $\mathrm{Th}$ & $\mathrm{Me}$ & All the year & All the year \\
\hline 343 & $\begin{array}{c}\text { Withania somnifera }(\mathrm{L} .) \text { Dunal } \\
\text { Thymelaeaceae }\end{array}$ & $\mathrm{H}$ & $\mathrm{Ch}$ & $\mathrm{Me}$ & July & Oct \\
\hline 344 & Daphne mucronata Royle & $\mathrm{S}$ & NanP & $\mathrm{N}$ & Nov & Feb \\
\hline 345 & $\begin{array}{c}\text { Daphne papyracea Wall. ex G. Don } \\
\text { Urticaceae }\end{array}$ & $\mathrm{S}$ & NanP & $\mathrm{N}$ & Nov & Feb \\
\hline 346 & $\begin{array}{c}\text { Lecanthus peduncularis (Wall. ex } \\
\text { Royle) Wedd. Weed. }\end{array}$ & $\mathrm{H}$ & HemC & $\mathrm{Mi}$ & July & Sept \\
\hline 347 & Pilea umbrosa Blume & $\mathrm{H}$ & $\mathrm{Th}$ & $\mathrm{Mi}$ & April & June \\
\hline 348 & $\begin{array}{c}\text { Urtica dioica } \mathrm{L} . \\
\text { Verbenaceae }\end{array}$ & $\mathrm{H}$ & $\mathrm{Th}$ & $\mathrm{Mi}$ & Sept & Oct \\
\hline 349 & $\begin{array}{l}\text { Pteracanthus urticifolius (Wall. ex } \\
\text { Kuntze) Bremek. }\end{array}$ & $\mathrm{H}$ & $\mathrm{Th}$ & $\mathrm{Me}$ & June & Aug \\
\hline 350 & $\begin{array}{c}\text { Verbena officinalis L. } \\
\text { Violaceae }\end{array}$ & $\mathrm{H}$ & $\mathrm{Th}$ & $\mathrm{Mi}$ & May & July \\
\hline 351 & Viola odorata L. & $\mathrm{H}$ & $\mathrm{Th}$ & $\mathrm{Mi}$ & Sept & Oct \\
\hline 352 & $\begin{array}{c}\text { Viola serpens Wall. Ex Ging } \\
\text { Vitaceae }\end{array}$ & $\mathrm{H}$ & $\mathrm{G}$ & $\mathrm{Mi}$ & Aug & Oct \\
\hline 353 & Vitex negundo L. & $\mathrm{S}$ & NanP & $\mathrm{Mi}$ & April & Aug \\
\hline 354 & Vitis jacquemontii R. Parker & $\mathrm{S}$ & NanP & $\mathrm{Me}$ & June & Aug \\
\hline
\end{tabular}

Abbreviations: H - Herb, Pp - Parasitic Plant, S - Shrub, T - Tree; Ch - Chamaephytes, G Geophytes, HemC - Hemicryptophytes, L - Liana, MegP - Megaphanerophytes, MesP Mesophanerophytes, MicP - Microphanerophytes, NanP - Nanophanerophytes, $\mathrm{Pp}$ - Parasitic plant, Th - Therophytes; Aph - Aphyllous, L - Leptophyll, Ma - Megaphyll, Me - Mesophyll, Mi - Microphyll, $\mathrm{N}$ - Nanophyll 